Concentrations of Mercury and Other Trace Elements in Walleye, Smallmouth Bass, and Rainbow Trout in

Franklin D. Roosevelt Lake and the Upper

Columbia River, Washington, 1994

By M.D. Munn, S.E. Cox, and C.J. Dean

U.S. Geological Survey

Open-File Report 95-195

Prepared in cooperation with the

U.S. ENVIRONMENTAL PROTECTION AGENCY and COLVILLE CONFEDERATED TRIBES 


\section{U.S. DEPARTMENT OF THE INTERIOR}

BRUCE BABBIT, Secretary

U.S. GEOLOGICAL SURVEY

Gordon P. Eaton, Director

Any use of trade, product, or firm names is for descriptive purposes only and does not imply endorsement by the U.S. Government.

For additional information write to:

District Chief

U.S. Geological Survey

1201 Pacific Avenue - Suite 600

Tacoma, Washington 98402
Copies of this report may be purchased from:

U.S. Geological Survey

Earth Science Information Center

Open-File Reports Section

Box 25286, MS 517

Denver Federal Center

Denver, Colorado 80225 


\section{CONTENTS}

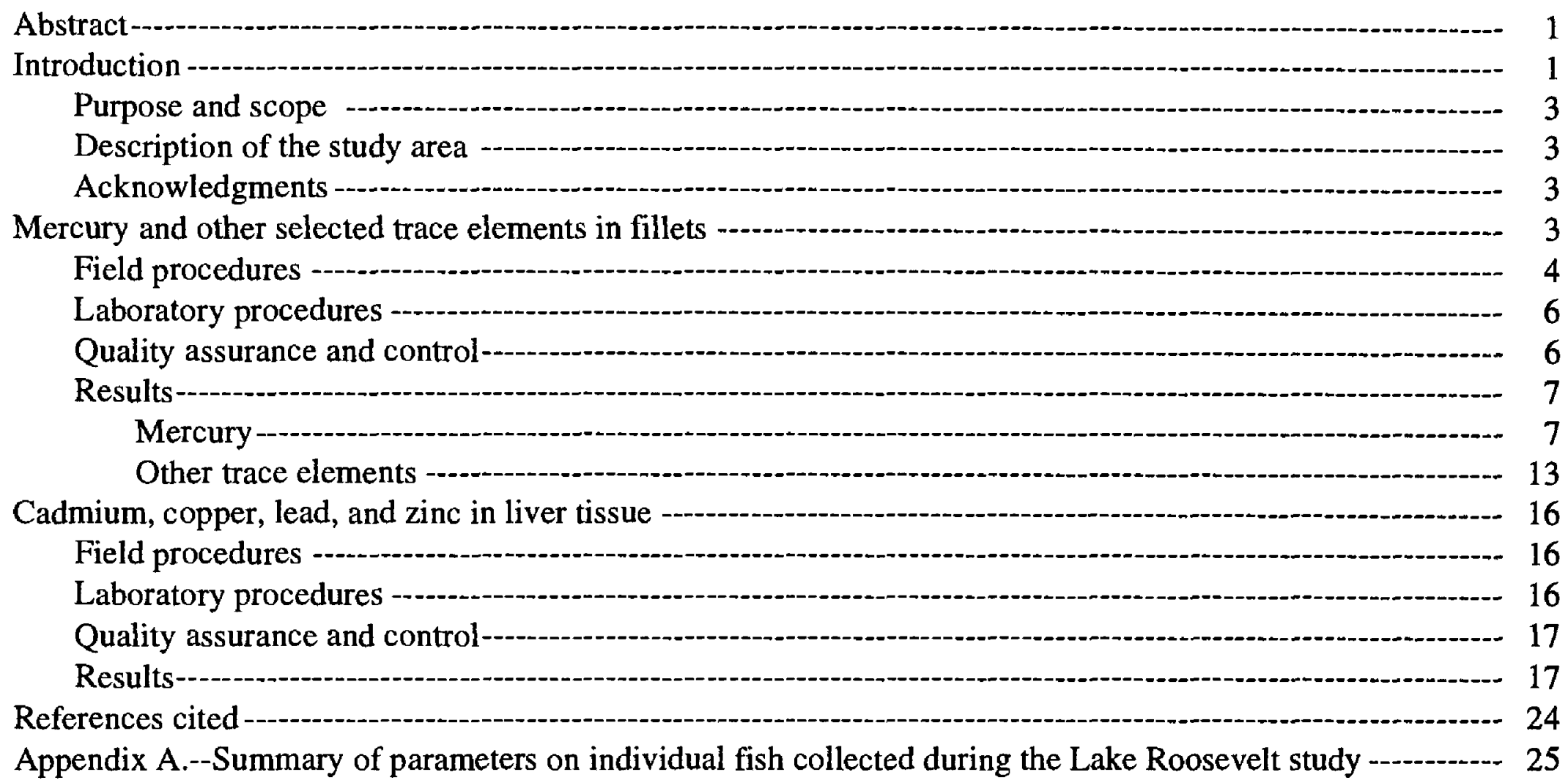

\section{FIGURES}

1. Map showing location of Franklin D. Roosevelt Lake and sampling locations-

\section{TABLES}

1. Samples collected for the analysis of total mercury and other selected trace elements in fillets of walleye, smallmouth bass, native rainbow trout, and net-pen rainbow trout-

2. Physical characteristics and age of walleye in composite samples and results of tissue analysis for total mercury by sampling location and size class

3. Concentrations of total mercury in individual fillets of 13- to 16-inch walleye compared to concentrations of total mercury in composite fillet samples

4. Concentrations of total mercury in smallmouth bass, native rainbow trout, and net-pen rainbow trout-

5. Concentrations of trace elements in hatchery rainbow trout used as field blanks for part of the quality assurance program-

6. Quality control results from the analysis of total mercury in walleye fish tissue and standard reference material-

7. Concentrations of selected trace elements in fillets of walleye, smallmouth bass, native rainbow trout, and net-pen rainbow trout-

8. Laboratory quality-control data for analysis of selected trace elements in edible fish fillets from Franklin D. Roosevelt Lake-

9. Samples collected for the analysis of selected trace elements in liver tissue of walleye, smallmouth bass, native rainbow trout, and net-pen rainbow trout- 


\section{TABLES-.-Continued}

10. Physical characteristics and age of sportfish and concentrations of cadmium, copper, lead, and zinc in liver tissue

11. Quality-control data for the analysis of cadmium, copper, lead, and zinc in liver tissue of walleye, smallmouth bass, and rainbow trout

\section{CONVERSION FACTORS AND VERTICAL DATUM}

[SI = International system of units $]$

\section{Multiply}

Inch-pound to international system units

$\begin{array}{rc}\text { inch (in) } & 25.4 \\ \text { foot (ft) } & 30.48 \\ \text { mile (mi) } & 1.609 \\ \text { acre } & 0.4047\end{array}$

International system units to inch-pound units

0.3937008
0.03937
0.03527

inch

inch

ounce avoidupois

Factors for converting SI metric units to other miscellaneous units

\section{Concentration, in water}

milligrams per liter $(\mathrm{mg} / \mathrm{L})$ micrograms per liter $(\mu \mathrm{g} / \mathrm{L})$

Concentration, in tissue and bed sediment millimeter

centimeter

kilometer

hectacre 


\title{
CONCENTRATIONS OF MERCURY AND OTHER TRACE ELEMENTS IN WALLEYE, SMALLMOUTH BASS, AND RAINBOW TROUT IN FRANKLIN D. ROOSEVELT LAKE AND THE UPPER COLUMBIA RIVER, WASHINGTON, 1994
}

\author{
By M.D. Munn, S.E. Cox, and C.J. Dean
}

\begin{abstract}
Three species of sportfish-walleye, smallmouth bass, and rainbow trout-were collected from Franklin D. Roosevelt Lake and the upstream reach of the Columbia River within the state of Washington, to determine the concentrations of mercury and other selected trace elements in tissue. Concentrations of total mercury in walleye fillets ranged from 0.11 to 0.44 milligram per kilogram, with the higher concentrations in the larger fish. Fillets of smallmouth bass and rainbow trout also contained mercury, but generally at lower concentrations. Other selected trace elements were found in fillet samples, but the concentrations were generally low depending on species and the specific trace element. The trace elements cadmium, copper, lead, and zinc were found in liver tissue of these same species with zinc consistently present in the highest concentration.
\end{abstract}

\section{INTRODUCTION}

Grand Coulee Dam was constructed on the Columbia River in Washington in the late 1930's and early 1940's to supply irrigation water, control flooding, and produce hydroelectric power. The reservoir it formed, Franklin D. Roosevelt Lake, commonly called Lake Roosevelt, has become a major recreational and economic resource for the surrounding area due in large part to sport fishing. The dominant sportfish in the Lake Roosevelt system includes walleye, rainbow trout, kokanee, yellow perch, and smallmouth bass (McDowell and Griffith, 1993). The Colville Confederated Tribes and the Spokane Tribe, whose reservations border parts of the reservoir, and local citizens and businesses also benefit from the reservoir fishery and its economic opportunities.

Several studies have raised concerns about whether concentrations of trace elements that bioaccumulate in fish from Lake Roosevelt are elevated to levels of concern to human and environmental health. This concern first surfaced when the U.S. Fish and Wildlife Service reported that concentrations of cadmium in whole fish collected from Lake Roosevelt were the largest of the 112 sites studied nationwide during the period of 1978 to 1980 (Lowe and others, 1985). While additional studies varied as to the species and type of tissue analyzed, arsenic, cadmium, copper, lead, mercury, and zinc were found in fish collected from Lake Roosevelt.

A 1992 study by the U.S. Geological Survey (USGS) reported that, relative to background reference sites, concentrations of arsenic, cadmium, copper, lead, mercury, and zinc were elevated in the bed sediments of Lake Roosevelt and of the Columbia River, its principal source of inflow (Bortleson and others, 1994). Of the trace elements measured, concentrations of copper, lead, and zinc most often exceeded the sediment-quality guidelines developed by the Ontario Ministry of Environment and Energy (Persaud and others, 1991). The elevated concentrations of trace elements in sediments of Lake Roosevelt and the upstream reach of the Columbia River are largely attributable to the transport of metallurgical waste and slag from a smelter discharging to the Columbia River in Canada (Bortleson and others, 1994).

Of the trace elements present, mercury is believed to be the element that most likely poses a threat to human health in Lake Roosevelt because mercury can bioconcentrate to elevated levels in fillets of fish that are then consumed by people (U.S. Environmental Protection Agency, 1992). Serdar (1993) reported that the concentrations of mercury in fillets of fish from Lake Roosevelt were elevated and that the largest concentrations were in walleye. Because of human health concerns, the USGS, in cooperation with Region 10 of the U.S. Environmental Protection Agency (USEPA) and the Lake Roosevelt Water Quality Council, designed and implemented a study to determine the concentrations of total mercury and other trace elements in fillets of selected sportfish in Lake Roosevelt and the upstream reach of the Columbia River (fig. 1). In order to increase the information gained from this study, the livers from the fish collected were also removed and were analyzed for concentrations of cadmium, copper, lead, and zinc. This part of the study was done in cooperation with the Colville Confederated Tribes. 


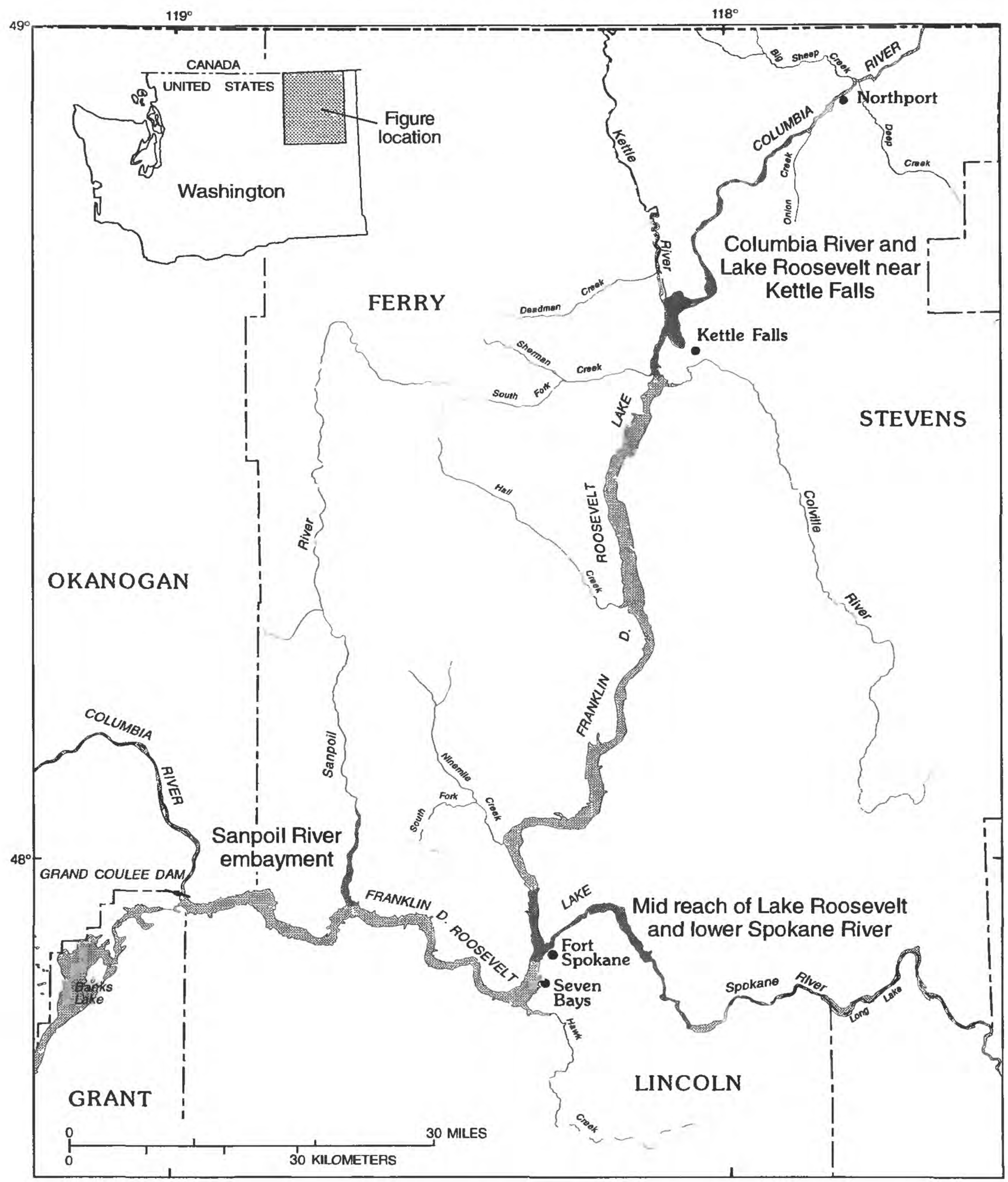

Figure 1.--Map showing location of Franklin D. Roosevelt Lake and sampling locations. 


\section{Purpose and Scope}

This report presents the data from the 1994 study on the bioaccumulation of trace elements in walleye (Stizostedion vitreum), smallmouth bass (Micropterus dolomieui), and rainbow trout (Oncorhynchus mykiss) in Lake Roosevelt and the upstream reach of the Columbia River. The primary objectives of this study were to:

1. Determine the concentrations of total mercury and other selected trace elements in fillets of walleye, smallmouth bass, and both native and net-pen rainbow trout; and

2. Determine the concentrations of cadmium, copper, lead, and zinc in the liver tissue of the same species.

Data obtained for the first objective will permit the USEPA (Region 10) and the Washington State Department of Health (WDOH) to assess the potential human health effects from the consumption of fish. Data obtained for the second objective will provide baseline data on the concentrations of cadmium, copper, lead, and zinc in fish livers. Both data sets provide a basis for assessing changes in contaminants over time.

\section{Description of the Study Area}

Lake Roosevelt is the largest reservoir by volume in Washington and one of the largest in the Nation in total storage. Located in north-central Washington, Lake Roosevelt extends about 135 miles upstream from the dam, reaching to within 15 miles of the international boundary with Canada, several miles below the town of Northport, Wash (fig. 1). The surface area of the lake is about 80,000 acres with a full-pool elevation of $1,289 \mathrm{ft}$. The stage level of the lake varies as much as 50 feet due to operation of Grand Coulee Dam. Historically, the mean annual retention time of water within the lake has been about 40 days. Additional data regarding Lake Roosevelt are provided by Bortleson and others (1994).

The study area included Lake Roosevelt and the part of the Columbia River upstream from the reservoir to Northport, Wash. The three sampling areas were the Sanpoil River embayment, the mid reach of Lake Roosevelt and lower Spokane River, and Columbia River and Lake Roosevelt near Kettle Falls.

\section{Acknowledgments}

This study could not have been completed without the assistance of many individuals and organizations. We thank the Spokane Walleye Club for collecting most of the walleye. We also thank Elizabeth Block of the U.S. Fish and Wildlife Service, Steven Goodbred of the National Biological Survey, David Terpening of the USEPA, and the Spokane Tribe for their assistance in the collection and processing of fish. The National Park Service at Fort Spokane provided accommodations for processing samples. The Washington State Department of Fish and Wildlife aged the fish used in this study.

\section{MERCURY AND OTHER SELECTED TRACE ELEMENTS IN FILLETS}

During May 16-21 and June 17-19, 1994, fish were collected for the study from three areas in the Lake Roosevelt and Columbia River system: the Sanpoil River embayment, the mid reach of Lake Roosevelt and lower Spokane River, and the Columbia River and Lake Roosevelt near Kettle Falls (fig. 1). These areas were selected for three primary reasons. (1) They are areas where walleye spawn, or pass through to spawn, and therefore contained a larger percentage of the older individuals required for the study. (2) The areas are commonly fished recreationally. (3) The geographical distribution of sites permitted a general assessment of the distribution of trace elements in fish within the entire reservoir and river system. Because the fish species used in this study move throughout part of (smallmouth bass) or all (rainbow trout and walleye) of the system, individual fish collected in one of the three areas are exposed to trace metals from much larger areas than the area of collection.

Walleye, one of the most commonly harvested species in Lake Roosevelt, were chosen because past studies have shown them to have the highest concentrations of mercury (Serdar, 1993). Smallmouth bass and rainbow trout were also chosen because they are popular sportfish, but were collected in a smaller sampling effort. Both native and net-pen rainbow trout were collected, but were analyzed separately in this study because native rainbow trout are exposed to trace metals throughout their life cycles in the reservoir, whereas net-pen rainbow trout spend their first year in suspended enclosures and are fed commercial food. 


\section{Field Procedures}

The field procedures apply generally to collection of fish used for both fillet and liver analyses in this study. Specific methods for collecting fish livers are described in the section "Cadmium, Copper, Lead, and Zinc in Liver Tissue". The size class of fish accepted for this study and the type of sample used (composite versus individual) varied depending on the species and availability (table 1). Walleye were collected from four size classes: 10 to $13 \mathrm{in}$., greater than 13 to $16 \mathrm{in}$., greater than 16 to $19 \mathrm{in}$., and greater than 19 to $22 \mathrm{in}$. A total of 34 walleye composite samples were collected, each composite consisting of 8 individual fillets from fish of the same size class. To determine whether the concentration of mercury from a composite sample was similar to the average mercury concentration from individual fish samples, a single composite sample from each of the three sampling areas was selected from the size class greater than 13 to 16 in. For these three composite samples, the fillets on the opposite side of the fish were removed and analyzed individually for total mercury.

Smallmouth bass were sampled the same as the walleye, except that fish were collected in a single size class of 8 to 12 inches (table 1). Rainbow trout were not sorted into size class, but were analyzed as individuals. All samples were analyzed for concentrations of total mercury. All smallmouth and rainbow samples were also analyzed for other trace elements, but only a subset of the walleye samples were analyzed (table 1).

Fish were collected using two methods. Most of the walleye were collected with hook and line, and individuals of all three species were collected using an electroshock boat. The total length of each fish was measured in order to assign it to size class. Any fish not needed to complete a composite sample within a specific size class was released. The fish that were used were sacrificed, placed in a labelled and sealed plastic bag, and stored on ice in a cooler until processed. Contacts between fish and other objects were minimized.
Fish were transported to a USGS mobile laboratory at Fort Spokane for processing before being sent to the analytical laboratory; all fish were processed within 24 hours of collection. The first processing step was to collect basic physical information on each fish: total length, from the anterior-most part of the fish to the tip of the longest caudal fin ray when the lobes of the caudal fin are compressed dorsoventrally, in millimeters; and total weight, in grams. Fish scales were collected and sent to the Washington State Department of Fish and Wildlife for age determination.

Field processing equipment was made of glass, plastic, or stainless steel. Strict guidelines were followed in the cleaning of all equipment that came into contact with samples, and equipment was cleaned between each composite or individual sample. Cleaning procedures for glass and plastic included washing equipment with phosphatefree laboratory detergent solution, rinsing in Type I reagent-grade water, rinsing in 5-percent nitric acid, rinsing in pesticide-grade methanol, permitting to air dry, and then storing in sealed containers. All dissection equipment was stainless steel and was cleaned using the above cleaning procedures, except for the 5-percent nitric acid rinse.

Fillet samples were removed in accordance with procedures in U.S. Environmental Protection Agency (1993), which included the belly flap. Filleting was done on glass or teflon cutting boards with stainless steel dissecting equipment. Once the fillet was obtained and the skin was removed, the fillet was then weighed (grams) and placed in a plastic bag that was sealed and placed on dry ice for shipment. Individual fish were then opened to determine sex and to remove the liver. All tissue samples were shipped to the USGS National Water Quality Laboratory (NWQL) in Arvada, Colo. 
Table 1.--Samples collected for the analysis of total mercury and other selected trace elements in fillets of walleye, smallmouth bass, native rainbow trout, and net-pen rainbow trout

[mg/kg, milligrams per kilogram; nc, none collected; RM, river mile; >, greater than]

\begin{tabular}{|c|c|c|c|c|c|c|c|c|}
\hline \multirow{3}{*}{$\frac{\text { Species }}{\text { Walleye }}$} & \multirow{2}{*}{\multicolumn{2}{|c|}{$\begin{array}{l}\text { Size class, } \\
\text { in inches } \\
\text { (centimeters } \\
\text { in parentheses) }\end{array}$}} & \multicolumn{2}{|c|}{$\begin{array}{l}\text { Sanpoil River } \\
\text { embayment }^{1}\end{array}$} & \multicolumn{2}{|c|}{$\begin{array}{l}\text { Mid reach of Lake } \\
\text { Roosevelt and lower } \\
\text { Spokane River }\end{array}$} & \multicolumn{2}{|c|}{$\begin{array}{l}\text { Columbia River and } \\
\text { Lake Roosevelt near } \\
\text { Kettle Falls }\end{array}$} \\
\hline & & & \multirow{2}{*}{$\begin{array}{l}\begin{array}{l}\text { Number of } \\
\text { samples }\end{array} \\
1\end{array}$} & \multirow{2}{*}{$\begin{array}{l}\begin{array}{l}\text { Number } \\
\text { of fillets } \\
\text { per sample }\end{array} \\
8\end{array}$} & \multirow{2}{*}{$\begin{array}{l}\begin{array}{l}\text { Number of } \\
\text { samples }\end{array} \\
5\end{array}$} & \multirow{2}{*}{$\begin{array}{l}\begin{array}{l}\text { Number } \\
\text { of fillets } \\
\text { per sample }\end{array} \\
8\end{array}$} & \multirow{2}{*}{$\frac{\begin{array}{l}\text { Number of } \\
\text { samples }\end{array}}{1}$} & \multirow{2}{*}{$\begin{array}{l}\begin{array}{l}\text { Number } \\
\text { of fillets } \\
\text { per sample }\end{array} \\
\frac{8}{4}\end{array}$} \\
\hline & ${ }^{4} 10-13$ & $(25.4-33)$ & & & & & & \\
\hline & ${ }^{4}>13-16$ & $(>33-40.6)$ & 2 & 8 & 7 & 8 & 6 & 8 \\
\hline & $5^{5}>13-16$ & $(>33-40.6)$ & 8 & 1 & 8 & 1 & 8 & 1 \\
\hline & $6>13-16$ & $(>33-40.6)$ & 1 & 8 & 1 & 8 & 1 & 8 \\
\hline & ${ }^{4}>16-19$ & $(>40.6-48.3)$ & 2 & 8 & 3 & 8 & 4 & 8 \\
\hline & $4>19-22$ & $(>48.3-55.9)$ & $\mathrm{nc}$ & $\mathrm{nc}$ & 2 & 8 & 1 & 8 \\
\hline $\begin{array}{l}\text { Smallmouth } \\
\text { bass }\end{array}$ & $4,68-12$ & $(20.3-30.5)$ & 3 & 5 & 2 & 5 & $\mathrm{nc}$ & $\mathrm{nc}$ \\
\hline $\begin{array}{l}\text { Native } \\
\text { rainbow trout }\end{array}$ & $4,619-22$ & $(48.3-55.9)$ & 4 & 1 & $\mathrm{nc}$ & $\mathrm{nc}$ & 2 & 1 \\
\hline $\begin{array}{l}\text { Net-pen } \\
\text { rainbow trout }\end{array}$ & $4,617-20$ & $(43.2-50.8)$ & 2 & 1 & $\mathrm{nc}$ & $\mathrm{nc}$ & $\mathrm{nc}$ & nc \\
\hline
\end{tabular}

'Sampling reach included the Sanpoil River embayment from its confluence with the Columbia River to the inflow of the Sanpoil River into the embayment.

${ }^{2}$ Sampling reach included Lake Roosevelt from RM 638.9 to RM 644.5 and the lower Spokane River from RM 0 to RM 17.

${ }^{3}$ Sampling reach included Lake Roosevelt below Kettle Falls (RM 705) to Columbia River at Northport (RM 735).

${ }^{4}$ Samples were analyzed for total mercury at a detection limit of $0.05 \mathrm{mg} / \mathrm{kg}$.

5 Individual fillet samples were removed from the opposite side of a fish used in a composite sample of the same size class.

${ }^{6}$ Samples were analyzed for (detection limits) arsenic $(0.1 \mathrm{mg} / \mathrm{kg})$, cadmium $(0.03 \mathrm{mg} / \mathrm{kg})$, copper $(0.1 \mathrm{mg} / \mathrm{kg})$, lead $(0.05 \mathrm{mg} / \mathrm{kg})$, manganese $(0.01 \mathrm{mg} / \mathrm{kg})$, selenium $(0.2 \mathrm{mg} / \mathrm{kg})$, and zinc $(0.3 \mathrm{mg} / \mathrm{kg})$. 


\section{Laboratory Procedures}

The USGS NWQL homogenized the fillets in stainless steel blenders using clean procedures. Homogenized muscle tissue samples were placed in pre-cleaned and certified sample jars, labelled, and shipped frozen (packed on dry ice) to the USEPA laboratory in Manchester, Wash., for chemical analysis; a chain-of-custody form accompanied each sample. For mercury samples, the USEPA laboratory used cold vapor atomic absorption spectrometry, as outlined in Method 245.6 (U.S. Environmental Protection Agency, 1991a). The detection limit for this procedure is $0.05 \mathrm{mg} / \mathrm{kg}$ (parts per million, wet weight). The USEPA Laboratory in Manchester used ICP-MS for the analysis of arsenic (at a detection of $0.1 \mathrm{mg} / \mathrm{kg}$ ), cadmium $(0.03 \mathrm{mg} / \mathrm{kg})$, copper $(0.1 \mathrm{mg} / \mathrm{kg})$, manganese $(0.01 \mathrm{mg} / \mathrm{kg})$, lead $(0.05 \mathrm{mg} / \mathrm{kg})$, selenium $(0.2 \mathrm{mg} / \mathrm{kg})$, and zinc $(0.3 \mathrm{mg} / \mathrm{kg})$. Laboratory analyses followed methods outlined in Method 200.8 (U.S. Environmental Protection Agency, 1991b).

\section{Quality Assurance and Control}

Quality assurance and control were used to insure the collection, processing, and analysis of data of a known and acceptable quality. Quality assurance of sample data included initial examination of captured fish, review by laboratory personnel of calibration standards and labgenerated quality-assurance samples, and review by project quality-assurance personnel of field and laboratory generated quality-control samples. Potential for contamination was minimized by using clean field procedures (described earlier) and by using dedicated field equipment for each sample. Samples were transported to a field laboratory where they were processed within 24 hours; a chain-of-custody form accompanied all samples. Field quality-control samples permitted an assessment of whether field procedures used were "clean". Laboratory quality control was established to assess sample contamination that might occur during the analytical process, and to assess analytical accuracy and precision.

A variety of quality-control samples was used to assess data quality, including field and laboratory blanks to assess potential contamination; laboratory matrix spike samples to assess analytical procedures; and analysis of duplicate sample material to assess analytical accuracy and data precision.

Field blanks were used to assess contamination that might have occurred during sample collection, field processing, and the homogenization of samples in the labora- tory. Nine "clean" hatchery-reared fish were used to make up field and process blank samples. The field-blank fish were rainbow trout provided by the USEPA laboratory in Manchester which had been reared under controlled conditions. The field-blank fish were sacrificed, wrapped individually, and taken to the field on ice, along with the sampling and processing equipment. "Clean" rainbow trout were inserted in the sample group at the point of fish capture from the lake and processed identically to fieldgathered samples. Individual fillets from three field-blank fish were combined into a single composite sample for each sampling site. The three composite field-blank samples were processed, homogenized, and analyzed in the same manner as the study samples.

Analytical procedures were assessed for accuracy through the analysis of procedural blanks and matrix spike samples. Matrix spike samples were prepared by the addition of a known quantity of the analyte to a duplicate sample. Recovery efficiency is based on the comparison of the results from the analysis of the matrix spike sample with the expected concentration. The acceptance criterion used in this study for the matrix spike recovery was from 80 to 120 percent.

The accuracy of the mercury and trace element data was assessed by analyzing DORM-2 standard reference material and by comparing the results of four duplicate samples analyzed by three independent laboratories. The DORM-2 standard is composed of dogfish muscle tissue and was selected because it more closely resembles the sample matrix of this study than other available standard reference material. These standards are prepared by the National Research Council of Canada.

Interlaboratory duplicate samples were prepared for comparative analysis during the homogenization procedures. The interlaboratory comparison samples were submitted to the project lab (USEPA Manchester Laboratory) and two additional laboratories (Battelle Marine Sciences Laboratory in Sequim, Wash., and Frontier Geosciences Laboratory in Seattle, Wash.). Data accuracy was considered acceptable if the relative percent difference of concentrations of mercury from the USEPA project laboratory was within 20 percent of the reported analysis of both Battelle Marine Science Laboratory and Frontier Geosciences Laboratory.

The precision of sample processing, including sample homogenization and analytical determinations, was determined by comparing duplicate analyses of environmental samples. Duplicate samples were generated under two conditions. Laboratory duplicate samples were prepared 
by the analyzing laboratory, whereas blind duplicates were prepared during the homogenization process and submitted to the analytical laboratory as blind samples. Analytical precision was considered acceptable if the relative percent difference between duplicate samples was within 20 percent.

\section{Results}

\section{Mercury}

Data on the concentrations of total mercury in fillets of walleye are shown in table 2. Concentrations ranged from 0.11 to $0.44 \mathrm{mg} / \mathrm{kg}$ with the lowest concentrations reported from the 10 to 13 inches size class and the highest concentrations found in the greater than 19 to 22 inches size class. Table 3 compares data on the concentrations of total mercury in three composite samples with the average concentration of mercury from individual fillets from the same composite samples. As shown, the concentration of mercury in composite samples closely approximates the average value based upon eight individual fillets from the same fish used in the composite samples. Percent moisture was also similar between composite samples and average values for the same fish.

Data on total mercury in smallmouth bass, native rainbow trout and net-pen rainbow trout are presented in table 4. Concentrations of total mercury in smallmouth bass ranged from 0.16 to $0.62 \mathrm{mg} / \mathrm{kg}(\mathrm{n}=5)$, native rainbow trout from 0.16 to $0.24 \mathrm{mg} / \mathrm{kg}(\mathrm{n}=6)$, and net-pen rainbow trout from 0.11 to $0.16 \mathrm{mg} / \mathrm{kg}(\mathrm{n}=2)$. All field data collected on individual fish are presented in Appendix A.

The results of the quality-control samples associated with samples analyzed for the concentration of mercury in fish tissues were all within the quality-assurance criteria. This indicated that the mercury data are acceptable with respect to the absence of contamination and to the reliability of data accuracy and precision.
The concentrations of mercury and other selected trace elements in the three rainbow trout composite fieldblank samples are shown in table 5. The concentration of mercury in all three field blank composite samples was below the detection limit of $0.05 \mathrm{mg} / \mathrm{kg}$, indicating no detectable mercury contamination had resulted from sample handling. Procedural blanks were included in each group of samples analyzed. Analysis of all laboratory procedural blank samples resulted in concentrations of mercury and the selected trace elements below the detection levels, indicating no detectable contamination had occurred during analysis.

Data accuracy was assessed through interlaboratory comparison of duplicate samples and the analysis of standard reference materials. The results of the analysis of mercury and the analysis of the DORM-2 standard in duplicate samples by independent laboratories are shown in table 6. The relative percent differences in the reported concentration of mercury from duplicate samples submitted to the USEPA project lab and two outside laboratories were within the 20-percent acceptance range. All labs reported the concentration of mercury in the DORM-2 standard reference material within the acceptable range; two of the labs reported concentrations within the certified range, which is the 95-percent tolerance limit cited by the supplier. These data indicate that the reported mercury concentrations are accurate and reliable. The acceptability criterion for the analysis of the DORM-2 standard was 80-120 percent of the certified value.

Blind replicate samples were sent to the USEPA project laboratory to assess the precision of the analysis of mercury concentrations. The identity of the blind qualit$y$-assurance samples was not known to the USEPA project laboratory. Data from the blind replicate samples, as well as duplicate samples generated within the laboratory, are shown in table 6 . The relative percent difference of the six blind duplicate pairs ranged from 0.5 to 11.4 percent. The relative percent difference of six duplicate laboratorygenerated sample pairs ranged from 1.3 to 12.5 percent. The relative percent differences of replicate analyses were within the quality-assurance criteria of 20 percent, indicating acceptable laboratory analytical precision. 
Table 2.--Physical characteristics and age of walleye in composite samples and results of tissue analysis for total mercury by sampling location and size class. A sample consisted of compositing eight fillets with skin removed.

[USGS, U.S. Geological Survey; cm, centimeter; mg/kg, milligram per kilogram; >, greater than]

\begin{tabular}{|c|c|c|c|c|c|c|c|}
\hline \multirow{3}{*}{$\begin{array}{l}\text { Size class } \\
\text { (inches, } \\
\text { centimeters } \\
\text { in parentheses) }\end{array}$} & \multirow{3}{*}{$\begin{array}{l}\text { Composite } \\
\text { replicate }\end{array}$} & \multirow[b]{3}{*}{$\begin{array}{l}\text { USGS } \\
\text { sample } \\
\text { number }\end{array}$} & \multicolumn{3}{|c|}{ Physical characteristics and age } & \multirow{2}{*}{\multicolumn{2}{|c|}{ Laboratory analysis }} \\
\hline & & & Mean & Mean & Mean & & \\
\hline & & & $\begin{array}{l}\text { composite } \\
\text { length } \\
(\mathrm{cm})\end{array}$ & $\begin{array}{l}\text { composite } \\
\text { weight } \\
\text { (grams) }\end{array}$ & $\begin{array}{l}\text { composite } \\
\text { age } \\
\text { (years) }\end{array}$ & $\begin{array}{l}\text { Percent } \\
\text { moisture }\end{array}$ & $\begin{array}{l}\text { Mercury } \\
\text { (mg/kg,wet } \\
\text { weight) }\end{array}$ \\
\hline
\end{tabular}

Columbia River and Lake Roosevelt near Kettle Falls

$10-13$

(25.4-33)

$1 \quad 30$

\section{8}

261

2

80

0.21

$>13-16$

$(>33-40.6)$

$\begin{array}{ccc}1 & 14 & 36.5 \\ 2 & 19 & 38.9 \\ 3 & 15 & 38.0 \\ 4 & 55 & 36.5 \\ 5 & 57 & 37.9 \\ 6 & 58 & 36.5 \\ \text { Mean } & & 37.4\end{array}$

$>16-19$

(>40.6-48.3)

$\begin{array}{ccc}1 & 16 & 42.9 \\ 2 & 17 & 43.4 \\ 3 & 18 & 43.0 \\ 4 & 56 & 43.8 \\ \text { Mean } & & 43.3\end{array}$

42.9

43.4

393

491

454

386

439

$\frac{391}{426}$

\begin{tabular}{l}
2 \\
4 \\
3 \\
2 \\
3 \\
3 \\
\hline 3
\end{tabular}

81

.21

78

79

.21

$79 \quad .28$

$79 \quad .26$

80

.26
29

79

.26

$>19-22$

(>48.3-55.9)

1

21

50.3

1,047

79

.32

Mid-reach of Lake Roosevelt and lower Spokane River

10-13

(25.4-33)

1
2
3
4
5

$>13-16$

(>33-40.6)

\begin{tabular}{rr}
3 & 30.3 \\
4 & 30.9 \\
8 & 31.1 \\
51 & 31.1 \\
52 & 32.0 \\
\hline & 31.1
\end{tabular}

5

6

7

50

61

53

54

Mean

$\begin{array}{crrr}1 & 5 & 36.0 & 367 \\ 2 & 6 & 35.3 & 330 \\ 3 & 7 & 35.8 & 335 \\ 4 & 50 & 34.6 & 335 \\ 5 & 61 & 35.1 & 343 \\ 6 & 53 & 35.9 & 347 \\ 7 & 54 & \underline{35.7} & \underline{354} \\ \text { Mean } & & 35.5 & 344\end{array}$

206

219

233

235

251

229

367

330

335

335

343

347

$\frac{354}{344}$

1
1
2
2
$\frac{2}{2}$

2

2

2

2

2

2

$\frac{2}{2}$

\begin{tabular}{l}
80 \\
80 \\
80 \\
80 \\
\hline 80
\end{tabular}

.35

.29

.25

.36 
Table 2.--Physical characteristics and age of walleye in composite samples and results of tissue analysis for total mercury by sampling location and size class. A sample consisted of compositing eight fillets with skin removed--Continued

\begin{tabular}{|c|c|c|c|c|c|c|c|}
\hline \multirow[b]{2}{*}{$\begin{array}{l}\text { Size class } \\
\text { (inches, } \\
\text { centimeters } \\
\text { in parentheses) }\end{array}$} & \multirow[b]{2}{*}{$\begin{array}{l}\text { Composite } \\
\text { replicate }\end{array}$} & \multirow[b]{2}{*}{$\begin{array}{l}\text { USGS } \\
\text { sample } \\
\text { number }\end{array}$} & \multicolumn{3}{|c|}{ Physical characteristics and age } & \multicolumn{2}{|c|}{ Laboratory analysis } \\
\hline & & & $\begin{array}{l}\text { Mean } \\
\text { composite } \\
\text { length } \\
(\mathrm{cm})\end{array}$ & $\begin{array}{l}\text { Mean } \\
\text { composite } \\
\text { weight } \\
\text { (grams) }\end{array}$ & $\begin{array}{l}\text { Mean } \\
\text { composite } \\
\text { age } \\
\text { (years) }\end{array}$ & $\begin{array}{l}\text { Percent } \\
\text { moisture }\end{array}$ & $\begin{array}{l}\text { Mercury } \\
\text { (mg/kg,wet } \\
\text { weight) }\end{array}$ \\
\hline \multicolumn{8}{|c|}{ Mid-reach of Lake Roosevelt and lower Spokane River--Continued } \\
\hline$>16-19$ & 1 & 9 & 43.4 & 644 & 4 & 80 & 0.36 \\
\hline \multirow[t]{3}{*}{$(>40.6-48.3)$} & 2 & 10 & 44.1 & 666 & 5 & 80 & .35 \\
\hline & 3 & 59 & 43.7 & 632 & 5 & 80 & .40 \\
\hline & Mean & & 43.7 & 647 & 5 & 80 & .37 \\
\hline$>19-22$ & 1 & 1 & 50.5 & 1,034 & 5 & 78 & .44 \\
\hline \multirow[t]{3}{*}{$(>48.3-55.9)$} & 2 & 2 & 51.2 & 1,021 & 4 & 77 & .33 \\
\hline & Mean & & $\overline{50.9}$ & $\overline{1,028}$ & 5 & 78 & .38 \\
\hline & & & \multicolumn{3}{|c|}{$\underline{\text { Sanpoil River embayment }}$} & & \\
\hline $\begin{array}{l}10-13 \\
(25.4-33)\end{array}$ & 1 & 12 & 30.4 & 205 & 1 & 79 & .11 \\
\hline$>13-16$ & 1 & 11 & 35.3 & 344 & 2 & 78 & .36 \\
\hline \multirow[t]{2}{*}{$(>33-40.6)$} & 2 & 27 & 38.0 & 409 & 3 & 80 & .37 \\
\hline & Mean & & $\overline{36.7}$ & $\overline{377}$ & 2 & 79 & .36 \\
\hline$>16-19$ & 1 & 13 & 42.7 & 617 & 3 & 79 & .36 \\
\hline \multirow[t]{2}{*}{$(>40.6-48.3)$} & 2 & 23 & 43.4 & 726 & 3 & 78 & .42 \\
\hline & Mean & & $\overline{43.1}$ & $\overline{672}$ & 3 & 78 & .39 \\
\hline
\end{tabular}


Table 3.--Concentrations of total mercury in individual fillets of 13-to 16-inch walleye compared to concentrations of total mercury in composite fillet samples. Composite samples consisted of combining eight fillets with skin removed, from the opposite side of the walleye used for the individual fillet samples.

[USGS, U.S. Geological Survey; mg/kg, milligrams per kilogram, wet weight; RM, river mile]

\begin{tabular}{|c|c|c|c|c|c|c|c|c|c|}
\hline \multirow[b]{2}{*}{$\begin{array}{l}\text { Repli- } \\
\text { cate }\end{array}$} & \multicolumn{3}{|c|}{ Sanpoil River embayment ${ }^{1}$} & \multicolumn{3}{|c|}{$\begin{array}{l}\text { Mid reach of Lake Roosevelt } \\
\text { and lower Spokane River }\end{array}$} & \multicolumn{3}{|c|}{$\begin{array}{l}\text { Columbia River and Lake } \\
\text { Roosevelt near Kettle Falls }{ }^{3}\end{array}$} \\
\hline & $\begin{array}{l}\text { USGS } \\
\text { sample } \\
\text { number }\end{array}$ & $\begin{array}{l}\text { Mercury } \\
(\mathrm{mg} / \mathrm{kg})\end{array}$ & $\begin{array}{l}\text { Percent } \\
\text { moisture }\end{array}$ & $\begin{array}{l}\text { USGS } \\
\text { sample } \\
\text { number }\end{array}$ & $\begin{array}{l}\text { Mercury } \\
(\mathrm{mg} / \mathrm{kg})\end{array}$ & $\begin{array}{l}\text { Percent } \\
\text { moisture }\end{array}$ & $\begin{array}{l}\text { USGS } \\
\text { sample } \\
\text { number }\end{array}$ & $\begin{array}{l}\text { Mercury } \\
(\mathrm{mg} / \mathrm{kg})\end{array}$ & $\begin{array}{l}\text { Percent } \\
\text { moisture }\end{array}$ \\
\hline \multicolumn{10}{|c|}{ Individual value } \\
\hline 1 & 27.1 & 0.15 & 79 & 6.1 & 0.31 & 91 & 14.1 & 0.14 & 80 \\
\hline 2 & 27.2 & 0.34 & 78 & 6.2 & 0.21 & 75 & 14.2 & 0.16 & 79 \\
\hline 3 & 27.3 & 0.43 & 79 & 6.3 & 0.24 & 80 & 14.3 & 0.20 & 80 \\
\hline 4 & 27.4 & 0.42 & 79 & 6.4 & 0.26 & 80 & 14.4 & 0.15 & 74 \\
\hline 5 & 27.5 & 0.65 & 80 & 6.5 & 0.18 & 80 & 14.5 & 0.22 & 80 \\
\hline 6 & 27.6 & 0.36 & 80 & 6.6 & 0.28 & 78 & 14.6 & 0.30 & 79 \\
\hline 7 & 27.7 & 0.30 & 78 & 6.7 & 0.27 & 81 & 14.7 & 0.16 & 80 \\
\hline 8 & 27.8 & 0.26 & 80 & 6.8 & 0.30 & 78 & 14.8 & 0.18 & 79 \\
\hline Mean & & 0.36 & 79 & & 0.26 & 80 & & 0.19 & 79 \\
\hline \multicolumn{10}{|c|}{ Composite value } \\
\hline & 27 & 0.37 & 80 & 6 & 0.27 & 80 & 14 & 0.21 & 81 \\
\hline
\end{tabular}

${ }^{1}$ Sampling reach includes the Sanpoil River embayment from its confluence with the Columbia River to the inflow of the Sanpoil River into the embayment.

${ }^{2}$ Sampling reach includes Lake Roosevelt from RM 638.9 to RM 644.5 and the lower Spokane River from RM 0 to RM 17.

${ }^{3}$ Sampling reach includes Lake Roosevelt at Kettle Falls (RM 705) to Columbia River at Northport (RM 735). 
Table 4.--Concentrations of total mercury in smallmouth bass, native rainbow trout, and net-pen rainbow trout. Smallmouth bass samples were a composite of five fillets without skin, whereas rainbow trout samples were single fillets without skin.

[USGS, U.S. Geological Survey; cm, centimeter; mg/kg, milligrams per kilogram, wet weight]

\begin{tabular}{|c|c|c|c|c|c|c|c|c|c|}
\hline \multirow{3}{*}{\multicolumn{3}{|c|}{ Site name }} & \multirow{3}{*}{$\begin{array}{l}\text { USGS } \\
\text { sample } \\
\text { number }\end{array}$} & \multicolumn{4}{|c|}{ Physical characteristic and age } & \multirow{2}{*}{\multicolumn{2}{|c|}{ Laboratory analysis }} \\
\hline & & & & \multicolumn{2}{|c|}{ Length } & \multirow[b]{2}{*}{$\begin{array}{l}\text { Weight } \\
\text { (grams) }\end{array}$} & \multirow[b]{2}{*}{$\begin{array}{l}\text { Age } \\
\text { (years) }\end{array}$} & & \\
\hline & & & & (inches) & $(\mathrm{cm})$ & & & $\begin{array}{l}\text { Percent } \\
\text { moisture }\end{array}$ & $\begin{array}{l}\text { Mercury } \\
(\mathrm{mg} / \mathrm{kg})\end{array}$ \\
\hline \multicolumn{10}{|c|}{ Smallmouth bass $\underline{1}$} \\
\hline \multirow{3}{*}{\multicolumn{3}{|c|}{ Sanpoil River embayment }} & 24 & 10.3 & 26.3 & 244 & 2 & 78 & 0.62 \\
\hline & & & 25 & 10.3 & 26.2 & 263 & 2 & 79 & 0.17 \\
\hline & & & 26 & 10.2 & 25.8 & 239 & 2 & 79 & 0.27 \\
\hline \multirow{2}{*}{\multicolumn{3}{|c|}{$\begin{array}{l}\text { Mid reach of Lake Roosevel } \\
\text { and lower Spokane River }\end{array}$}} & t 28 & 9.8 & 24.8 & 236 & 2 & 79 & 0.16 \\
\hline & & & 29 & 10.5 & 26.6 & 253 & 2 & 79 & 0.19 \\
\hline \multicolumn{10}{|c|}{ Native rainbow trout ${ }^{2}$} \\
\hline \multirow{4}{*}{\multicolumn{3}{|c|}{ Sanpoil River embayment }} & 33 & 20.1 & 51.0 & 1,216 & 5 & 73 & 0.24 \\
\hline & & & 34 & 19.9 & 50.5 & 1,086 & 5 & 80 & 0.16 \\
\hline & & & 35 & 21.3 & 54.0 & 1,188 & 4 & 80 & 0.21 \\
\hline & & & 36 & 19.3 & 49.0 & 1,055 & 4 & 78 & 0.20 \\
\hline \multirow{2}{*}{\multicolumn{3}{|c|}{$\begin{array}{l}\text { Columbia River and Lake } \\
\text { Roosevelt near Kettle Falls }\end{array}$}} & 31 & 20.5 & 52.0 & 1,245 & 5 & 82 & 0.19 \\
\hline & & & 32 & 20.1 & 51.0 & 996 & 4 & 82 & 0.21 \\
\hline \multicolumn{10}{|c|}{ Net-pen rainbow trout $\underline{2}$} \\
\hline \multirow{2}{*}{\multicolumn{3}{|c|}{ Sanpoil River embayment }} & 37 & 17.9 & 45.5 & 1,219 & 3 & 77 & 0.16 \\
\hline & & & 38 & 20.1 & 51.0 & 1,563 & 3 & 72 & 0.11 \\
\hline \multirow{3}{*}{\multicolumn{10}{|c|}{$\begin{array}{l}{ }^{1} \text { A smallmouth bass sample consisted of a mean value from a composite sample of } 5 \text { fish. } \\
{ }^{2} \text { Native and net-pen rainbow trout samples are based on single fish samples. }\end{array}$}} \\
\hline & & & & & & & & & \\
\hline & & & & & & & & & \\
\hline \multicolumn{10}{|c|}{ Concentration of trace elements in milligrams per kilogram, wet weight } \\
\hline Sample & Arsenic & & admium & Copper & Lead & Manganese & Mercury & Selenium & Zinc \\
\hline 1 & 0.4 & & $<0.1$ & 0.66 & $<0.01$ & 0.19 & $<0.05$ & 0.37 & 4.7 \\
\hline 2 & 0.4 & & $<0.1$ & $<0.5$ & 0.13 & 0.16 & $<0.05$ & 0.32 & 4.5 \\
\hline 3 & 0.4 & & $<0.1$ & $<0.5$ & 0.21 & 0.14 & $<0.05$ & 0.33 & 3.7 \\
\hline
\end{tabular}




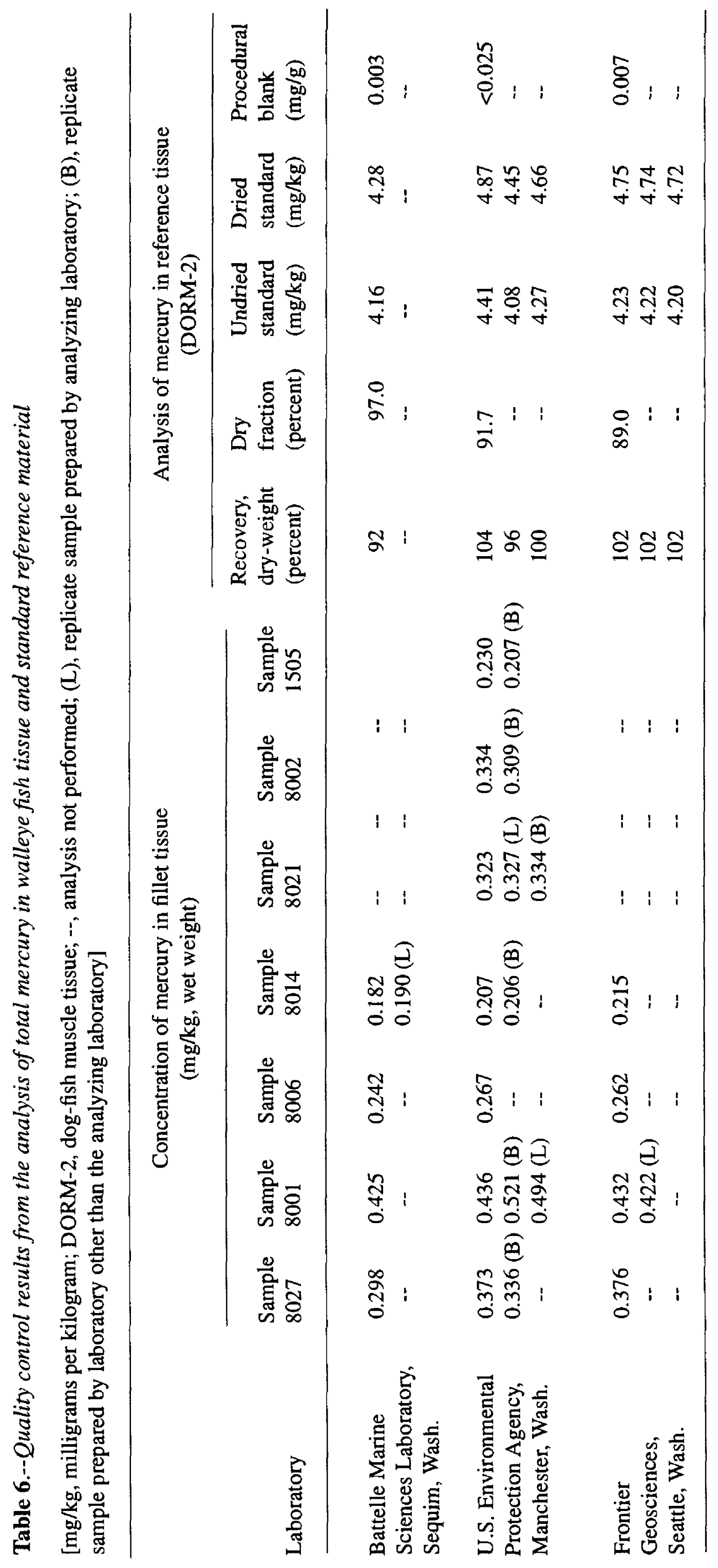




\section{Other Trace Elements}

The results of analyzing for other selected trace elements in fillets from walleye, smallmouth bass, and native and net-pen rainbow trout are shown in table 7. Concentrations of both arsenic and cadmium were below detection limits, or only slightly above, for all samples and species. Concentrations of copper in fillet tissue ranged from 0.27 to $0.68 \mathrm{mg} / \mathrm{kg}$, with largest concentrations measured in native rainbow trout collected from Sanpoil River embayment. Concentrations of lead ranged from below the detection limit of $0.05 \mathrm{mg} / \mathrm{kg}$ to $0.1 \mathrm{mg} / \mathrm{kg}$; four of the 16 samples had concentrations between 0.06 and

$0.1 \mathrm{mg} / \mathrm{kg}$. Manganese ranged from 0.09 to $0.54 \mathrm{mg} / \mathrm{kg}$, with most samples having similar concentrations among sites and species. Five of the samples showed below detection limits for selenium, with the remainder of the samples having concentrations between 0.22 and $0.39 \mathrm{mg} /$ $\mathrm{kg}$. Concentrations of zinc were the highest of all the trace elements measured with values ranging from 3.7 to $6.1 \mathrm{mg} / \mathrm{kg}$; however, 11 of the 16 samples were noted by the laboratory because spike sample recoveries associated with those 11 samples were outside the laboratory control limits. Therefore, concentrations of zinc for these samples are likely overestimated.

The results of the quality-control samples associated with samples analyzed for the concentration of arsenic, cadmium, copper, lead, manganese, selenium, and zinc in fish tissues were generally within the acceptance criteria. However, several quality-control samples were outside of the acceptable range and thus require that the data be noted appropriately. Overall, the data for arsenic, cadmium, copper, lead, manganese, and selenium are acceptable; zinc required some qualifications.

The concentrations of selected trace elements in the three field blanks ("clean" fish) were below detection limits for cadmium, with detections in at least one of the three replicates for each of the other trace elements. Of the trace elements measured, zinc consistently had the greatest concentrations, indicating either consistent contamination of the fish tissue samples with zinc or, more likely, the presence of zinc in the hatchery-reared fish.
Procedural blanks were included as part of the analytical methods in each group of samples analyzed and are shown in table 8. With the exception of zinc, the concentrations determined in the analysis of blanks were less than the detection limit concentration for the analysis. For zinc, the analysis of the blanks resulted in a concentration of 0.3 micrograms per gram which is the detection limit for that analysis and which is more than an order of magnitude smaller than the reported concentrations for zinc in the fish tissue samples. These data indicate no substantial or detectable contamination resulting from the analytical procedures.

Matrix spike recovery data are in table 8 . The recovery of matrix spike samples were within acceptable criteria for all trace elements except for one of two matrix spike samples for zinc. The acceptable range for matrix spike recovery data for this study is from 80 to 120 percent of the spike concentrations. Because one of the matrix spike recovery samples for zinc yielded recoveries of 131 and 136 percent, all of the zinc data in table 8 were noted to indicate this condition.

The accuracy of the trace element data was assessed by the analysis of standard reference materials (table 8). The acceptability criteria for the analysis of the standard reference material was 80-120 percent of the certified value. Reported concentrations of arsenic, copper, manganese, selenium, and zinc were within the acceptable range; copper and zinc were within the manufactures' certified range. The concentrations of cadmium and lead in the standard reference material reported by the project laboratory were above the certified concentrations for the standard reference material, indicating a small positive bias in the data. Because all of the cadmium concentrations reported for fish tissue samples were below the detection limit, a small positive bias of the magnitude suggested by the data in table 8 should not substantially affect the interpretation of the results. Similarly, all of the concentrations of lead reported for the fish tissue samples were below or near the detection limits, therefore a small positive bias of the magnitude suggested by the data should not substantially affect the interpretation of the results.

Duplicate analyses were performed for all seven trace elements from sub-samples generated by the project laboratory. All the duplicate analysis were within the relative percent difference guidelines of 20 percent (see table 8). 
Table 7.--Concentrations of selected trace elements in fillets of walleye, smallmouth bass, native rainbow trout, and net-pen rainbow trout

[USGS, U.S. Geological Survey; <, less than detectable levels; >, greater than]

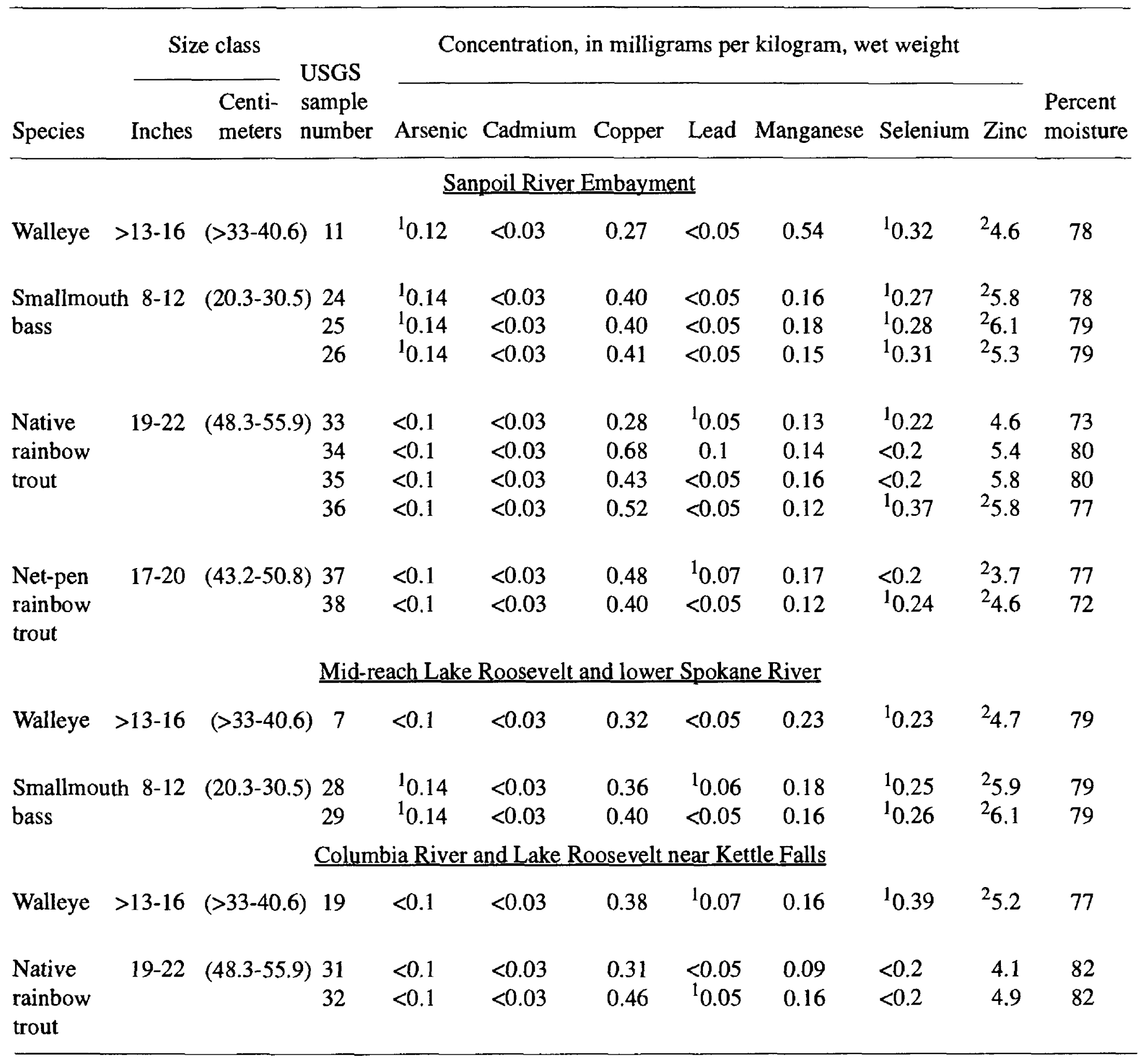

${ }^{1}$ The analyte was detected above the method detection limit but below the reporting limit, and therefore are estimates.

${ }^{2}$ One of the two (see table 8 ) spike samples recovery is not within control limits. 
Table 8.--Laboratory quality-control data for analysis of selected trace elements in fish fillets from Lake Roosevelt

[Values are concentrations in micrograms per gram, wet weight, unless otherwise noted; DORM-2, dog-fish muscle tissue; NIES, National Institute for Environmental Studies; <, less than]

\begin{tabular}{|c|c|c|c|c|c|c|c|}
\hline & Arsenic & Cadmium & Copper & Lead $^{1}$ & Manganese & Selenium & Zinc \\
\hline \multicolumn{8}{|c|}{ Procedural blank } \\
\hline Blank & $<0.1$ & $<0.03$ & $<0.1$ & $<0.05$ & $<0.01$ & $<0.2$ & 0.3 \\
\hline \multicolumn{8}{|c|}{$\underline{\text { Standard reference material }}$} \\
\hline DORM-2 or & 18.0 & 0.043 & 2.34 & -- & 3.66 & 1.40 & 25.6 \\
\hline NIES mussel & -- & -- & -- & 0.91 & -- & -- & -- \\
\hline $\begin{array}{l}\text { (95 percent } \\
\text { tolerance limits }\end{array}$ & \pm 1.1 & \pm 0.008 & \pm 0.16 & \pm .04 & \pm 0.34 & \pm 0.09 & \pm 2.3 \\
\hline $\begin{array}{l}\text { Analyzed concen- } \\
\text { trations in reference } \\
\text { material }\end{array}$ & 19.5 & 0.06 & 2.48 & 1.13 & 3.28 & 1.64 & 26.1 \\
\hline $\begin{array}{l}\text { Relative percent } \\
\text { difference of } \\
\text { reference material } \\
\text { with certified values }\end{array}$ & 8 & ${ }^{4} 33$ & 6 & 22 & 11 & 16 & 2 \\
\hline \multicolumn{8}{|c|}{ Matrix spike recovery (in percent) } \\
\hline $\begin{array}{l}\text { Spike } 1 \\
\text { Spike } 1 \text { duplicate }\end{array}$ & $\begin{array}{l}109 \\
111\end{array}$ & $\begin{array}{l}104 \\
107\end{array}$ & $\begin{array}{l}102 \\
103\end{array}$ & $\begin{array}{r}99 \\
101\end{array}$ & $\begin{array}{l}111 \\
109\end{array}$ & $\begin{array}{l}116 \\
116\end{array}$ & $\begin{array}{l}{ }_{4} 136 \\
{ }_{131}\end{array}$ \\
\hline $\begin{array}{l}\text { Spike } 2 \\
\text { Spike } 2 \text { duplicate }\end{array}$ & $\begin{array}{l}113 \\
109\end{array}$ & $\begin{array}{l}106 \\
103\end{array}$ & $\begin{array}{l}108 \\
103\end{array}$ & $\begin{array}{r}101 \\
99\end{array}$ & $\begin{array}{l}113 \\
108\end{array}$ & $\begin{array}{l}112 \\
111\end{array}$ & $\begin{array}{r}115 \\
95\end{array}$ \\
\hline \multicolumn{8}{|c|}{ Laboratory duplicate analysis } \\
\hline $\begin{array}{l}424 \\
424 \text { duplicate } \\
424 \text { relative percent }\end{array}$ & $\begin{array}{l}<0.1 \\
<0.1\end{array}$ & $\begin{array}{l}<0.03 \\
<0.03\end{array}$ & $\begin{array}{r}0.28 \\
.29\end{array}$ & $\begin{array}{l}{ }^{3} 0.05 \\
{ }^{3}<0.05\end{array}$ & $\begin{array}{l}0.134 \\
0.149\end{array}$ & $\begin{array}{l}30.22 \\
{ }^{3} 0.22\end{array}$ & $\begin{array}{l}4.62 \\
4.89\end{array}$ \\
\hline difference $^{2}$ & 0 & 0 & 3.5 & 0 & 10.6 & 0 & 5.7 \\
\hline 429 & $<0.1$ & $<0.03$ & 0.40 & $<0.05$ & 0.119 & ${ }^{3} 0.24$ & 4.62 \\
\hline 429 duplicate & $<0.1$ & $<0.03$ & .40 & $<0.05$ & .114 & ${ }^{3} 0.23$ & 4.36 \\
\hline $\begin{array}{l}429 \text { relative percent } \\
\text { difference }^{2}\end{array}$ & 0 & 0 & 0 & 0 & 4.3 & 4 & 5.8 \\
\hline
\end{tabular}

\footnotetext{
${ }^{1}$ NIES muscle tissue was used as reference material for lead; whereas for the other trace elements DORM-2 tissue was used.

${ }^{2}$ Relative percent difference $=(($ Lab concentration - certified concentration $) /($ Lab concentration + certified concentration/2) X 100.

${ }^{3}$ The analyte was detected above the method detection limit but below the established reporting limit, and therefore are estimates.

${ }^{4}$ Values exceeded quality-assurance guidelines.
} 


\section{CADMIUM, COPPER, LEAD, AND ZINC IN LIVER TISSUE}

The general procedures for field collection of fish are described in the section "Mercury and Other Selected Trace Elements in Fillets--FIeld Procedures". The field and laboratory procedures used specifically for the assessment of trace elements in liver tissue are presented here.

\section{Field Procedures}

Once the fillets were removed from the fish, the fish were opened and their livers removed using stainless steel dissecting equipment. Equipment cleaning procedures were identical to those described earlier; however, a separate set of dissecting equipment was used for extracting liver tissue. After removal, the livers were rinsed with distilled water, weighed, and placed into pre-weighed plastic jars. Samples were placed on dry ice and shipped to the analytical laboratory.
For both walleye and smallmouth bass, livers were composited from the same fish used in the fillet composite sample. Therefore, walleye samples contained eight livers, and smallmouth bass five livers. Rainbow trout livers were analyzed individually. Although all smallmouth bass and rainbow livers were analyzed, only a subset of the walleye composite liver samples were analyzed. Table 9 summarizes the samples collected in this study.

\section{Laboratory Procedures}

Once processed in the field, liver samples were frozen on dry ice and shipped to Battelle Marine Science Laboratories in Sequim, Wash., for analysis. Samples were freeze-dried, ground, digested in nitric acid, and analyzed by ICP/MS (Crecelius and others, 1993). Samples were analyzed for four trace elements (detection limits, in micrograms per gram, in parentheses): cadmium $(0.01 \mu \mathrm{g} / \mathrm{g})$, copper $(1.0 \mu \mathrm{g} / \mathrm{g})$, lead $(0.01 \mu \mathrm{g} / \mathrm{g})$, and zinc $(1.0 \mu \mathrm{g} / \mathrm{g})$. Percent moisture was also determined for all samples.

Table 9.--Samples collected for the analysis of selected trace elements in liver tissue of walleye, smallmouth bass, native rainbow trout, and net-pen rainbow trout. Livers were analyzed for cadmium, copper, lead, and zinc.

[nc, none collected; RM, river mile; >, greater than]

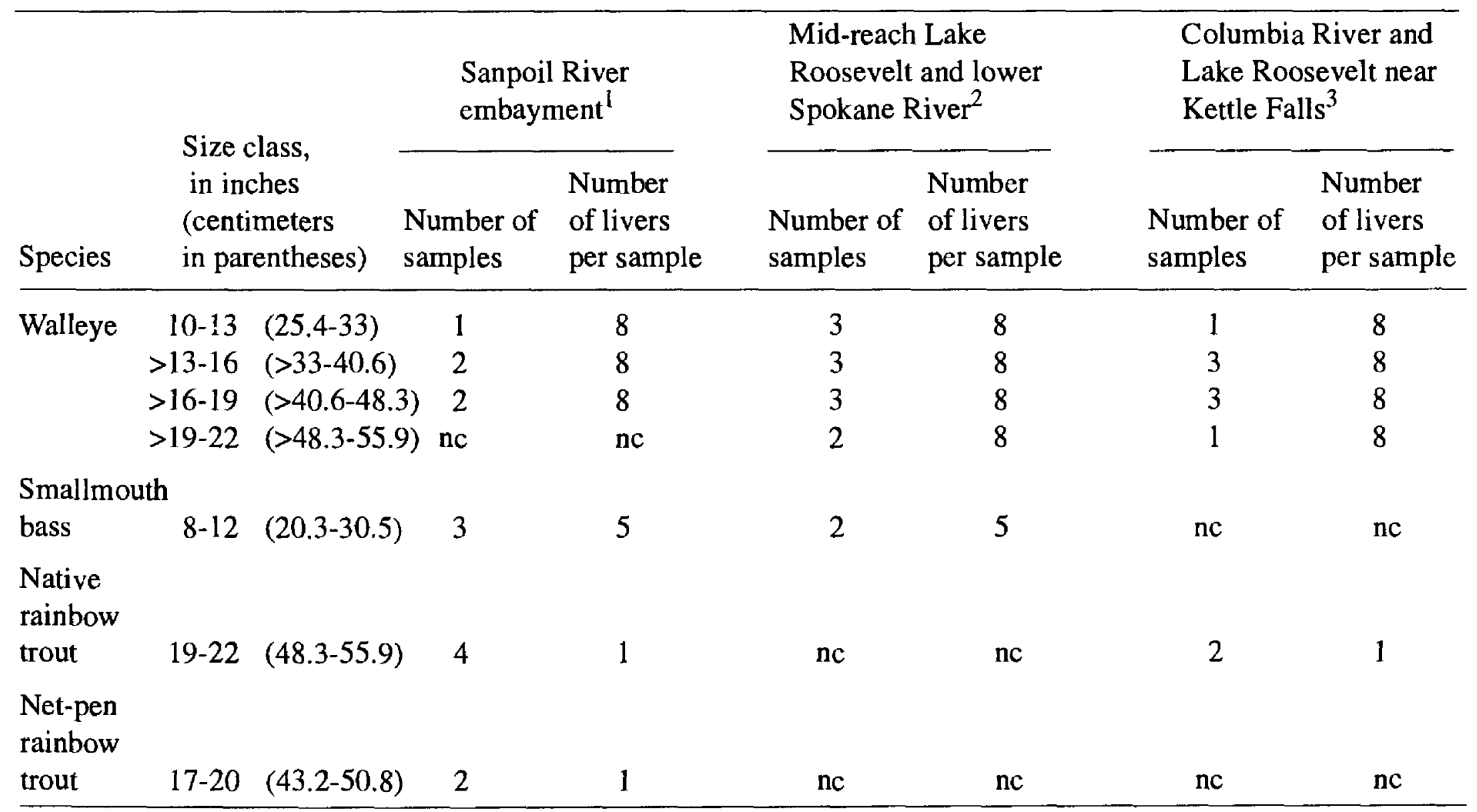

${ }^{1}$ Sampling reach includes the Sanpoil River embayment from its confluence with the Columbia River to the inflow of the Sanpoil River into the embayment.

${ }^{2}$ Sampling reach includes Lake Roosevelt from RM 638.9 to RM 644.5 and the lower Spokane River from RM 0 to RM 17.

${ }^{3}$ Sampling reach includes Lake Roosevelt at Kettle Falls (RM 705) to Columbia River at Northport (RM 735). 


\section{Quality Control and Assurance}

Quality-assurance and control were incorporated to assure the collection, processing, and analysis of data of a known and acceptable quality. Quality assurance of sample data included initial screening of captured fish; review by laboratory personnel of calibration standards and labgenerated quality-control samples; and review by project quality assurance personnel of field and laboratory generated quality-control samples. Quality-control samples were used to assess data quality of trace elements concentrations in liver tissue and included laboratory blanks to assess potential contamination, laboratory matrix spike samples to assess analytical procedures, and the analysis of standard reference material. Quality-control procedures included two procedural blanks, two matrix spikes, and two analyses of standard reference material. The standard reference material used in the analysis of liver tissue was DOLT-2 (dogfish liver tissue) prepared by National Research Center for Canada.

\section{Results}

The concentrations of cadmium, copper, lead, and zinc in liver tissue collected from the three species are shown in table 10. The concentrations of cadmium in liver tissue ranged from 0.9 to $15.7 \mu \mathrm{g} / \mathrm{g}$, with highest concentrations measured in walleye and native rainbow trout. Copper was highest in both native and net-pen rainbow trout, with values reaching $140 \mu \mathrm{g} / \mathrm{g}$ in native rainbow trout; smallmouth bass had the lowest concentrations. Concentrations of lead were similar among the three species and ranged from less than 0.03 to $10.9 \mu / \mathrm{g}$. Of the four trace elements, zinc showed the highest concentrations with values ranging from 64.6 to $622 \mu / \mathrm{g}$.

The results of the quality-control samples associated with samples analyzed for the concentration of cadmium, copper, lead, and zinc in fish liver tissues were generally within the quality assurance acceptance criteria. Several extreme values were present in the data, and review of these data with the project laboratory revealed that the results were not the result of analytical or typographical errors. Several of the standard reference material samples were outside of the acceptable range for either lead or zinc. Two standard reference materials were used and the exceedence of the quality control criteria were not found in both of the standard reference material samples. Overall, the data are of generally acceptable quality.

Procedural blanks were included as part of the analytical methods in each group of samples analyzed and are shown in table 11. Concentrations of the selected trace elements in the procedural blank samples were low, resulting in method detections lower than required for the analysis. Overall, the procedural blank data show no substantial or detectable contamination resulting from the analytical procedures.

The accuracy of the trace element data was assessed by the analysis of standard reference materials, the analysis of which are shown in table 11 . The acceptance criterion for the analysis of standard reference material was 80 to 120 percent of the certified concentration. Two standard reference materials were used in the analysis of liver tissue: the DOLT-2 of dogfish liver tissue from the National Research Council of Canada and the 1566a oyster tissue from the U.S. National Institute of Standards and Technology. With the exception of one of the lead analyses of the DOLT-2 standard, all results were within the relative percent difference guideline of 20 percent when compared to the certified concentrations. Duplicate analysis of zinc in the oyster tissue resulted in a relative percent difference of 26 percent, which is larger than the acceptability criteria of 20 percent; however, the triplicate analyses of the DOLT-2 standard for zinc were well within the precision guidelines. One triplicate analysis of lead in the DOLT 2 standard was quite low and resulted in relative percent differences larger than 20 percent; however, the remaining four lead analyses of standard reference material were within the precision guidelines. Matrix spike recovery data are shown for four different spiking levels in table 11. The data show acceptable spike recovery at all spiking levels. 


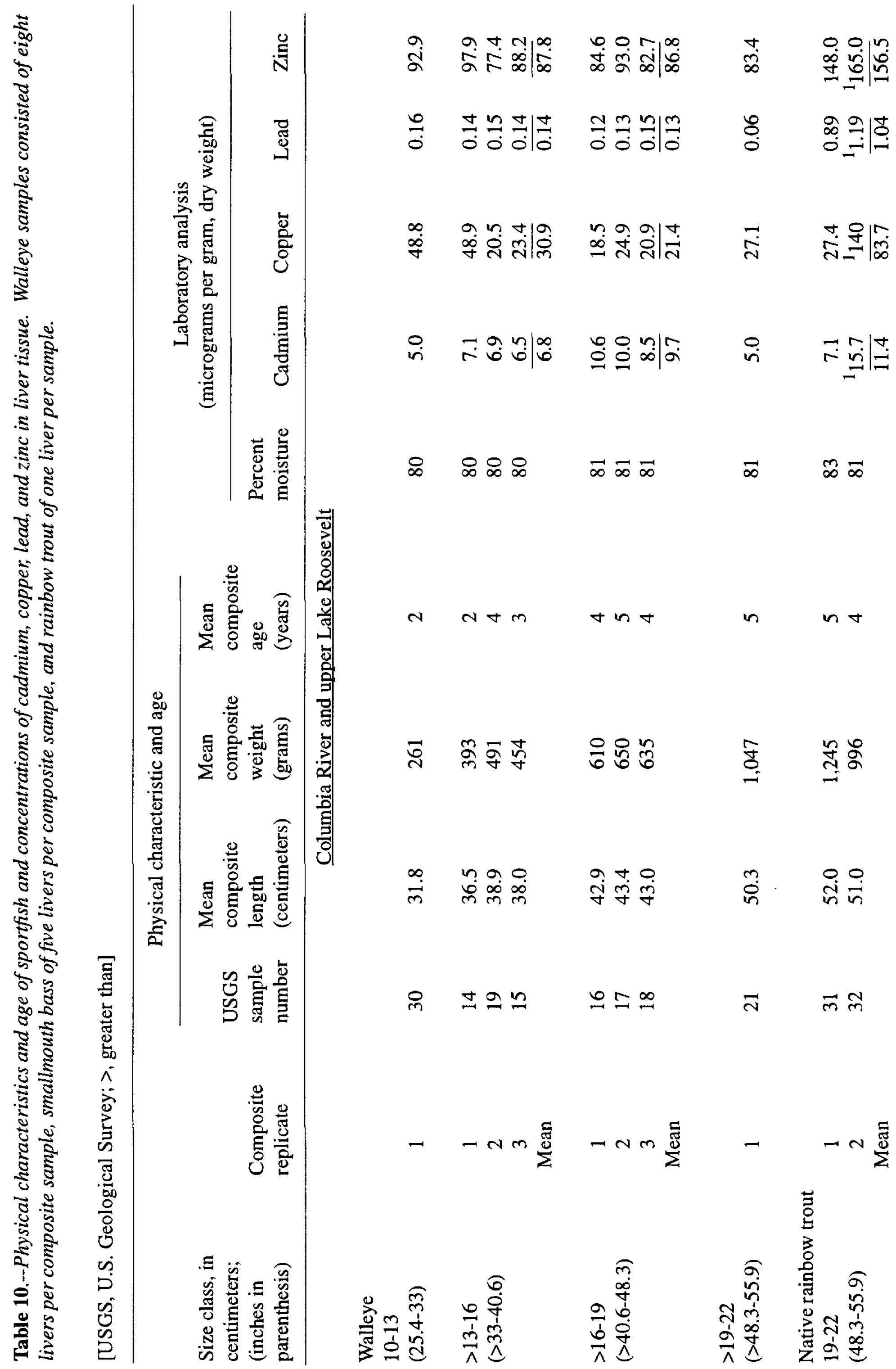




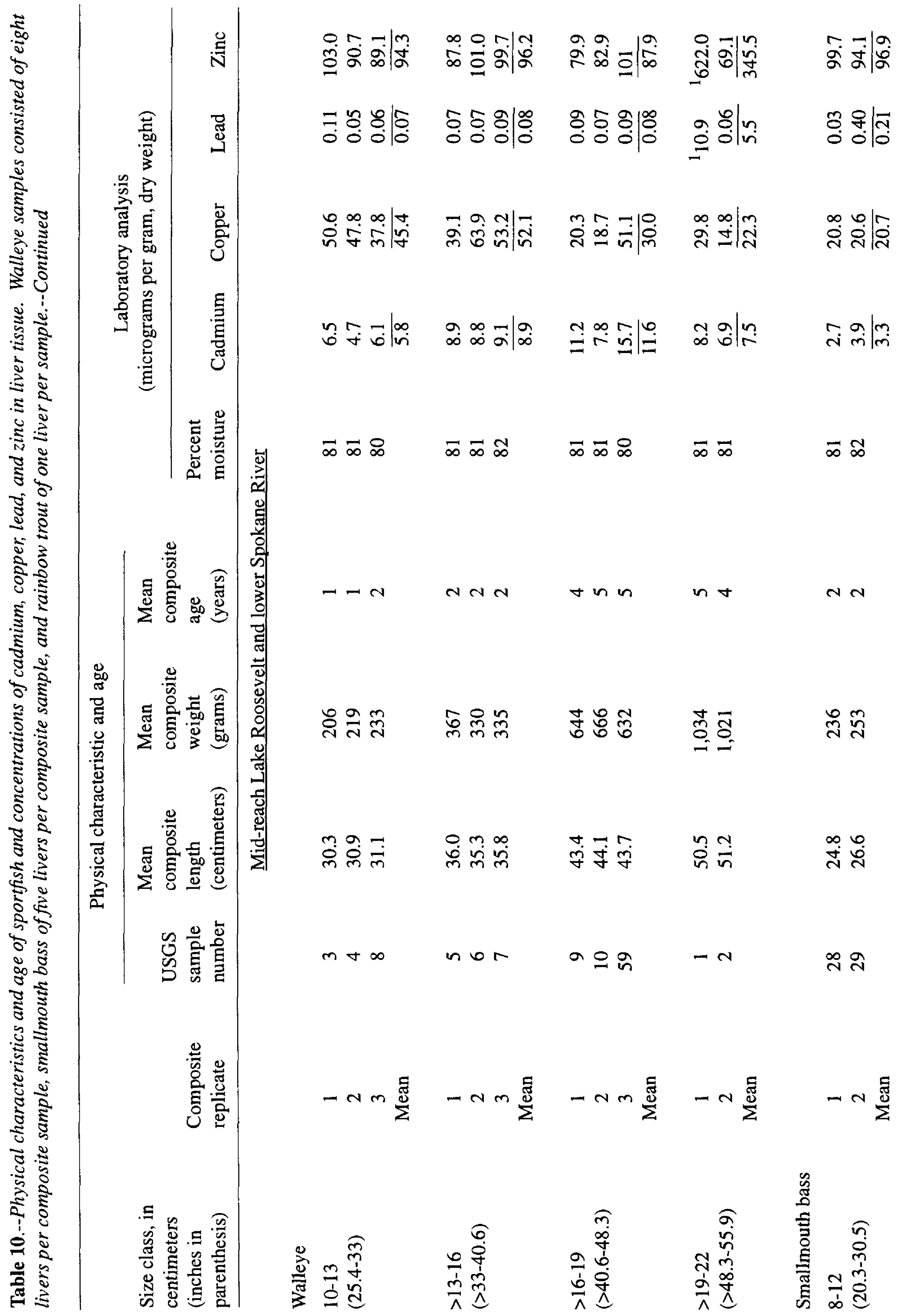




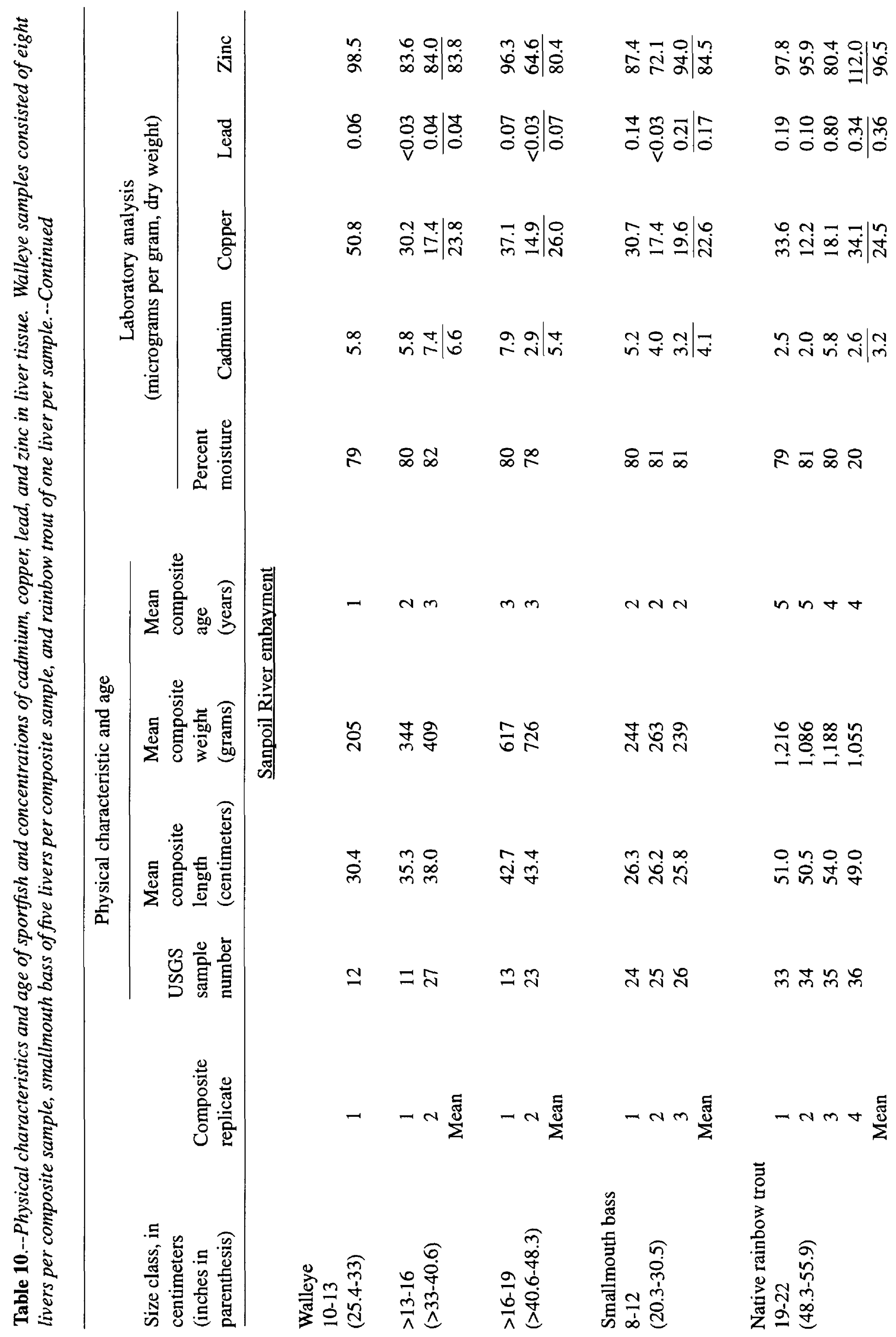




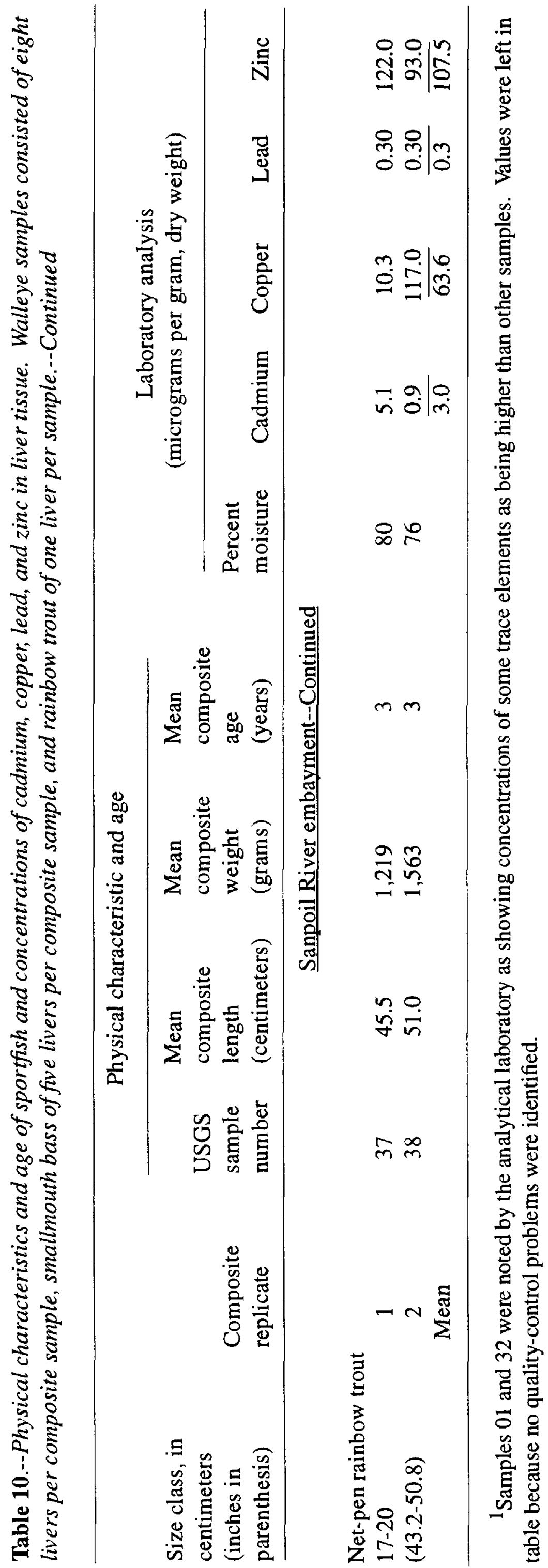


Table 11.--Quality-assurance data for the analysis of cadmium, copper, lead, and zinc in liver tissue of walleye, smallmouth bass, and rainbow trout. Inductively coupled plasma mass spectography (ICP/MS) analysis from Battelle Marine Science Laboratory, Sequim, Washington.

[SL, spiking level not adequate; DOLT-2, dog-fish liver tissue]

\begin{tabular}{lcccc}
\hline & \multicolumn{4}{c}{ Concentrations, in micrograms per gram, dry weight } \\
\cline { 2 - 5 } Sample description & Cadmium & Copper & Lead & Zinc \\
\hline & Blanks & & & \\
Blank-Replicate 1 & ${ }^{2} 0.005$ & ${ }^{2} 0.007$ & ${ }^{2} 0.007$ & ${ }^{2} 0.783$ \\
Blank-Replicate 2 & ${ }^{2} 0.007$ & ${ }^{2} 0.036$ & ${ }^{2} 0.016$ & 30.8 \\
Blank-Replicate 3 & ${ }^{2} 0.003$ & ${ }^{2} 0.018$ & ${ }^{2} 0.011$ & ${ }^{3} 0.8$ \\
Mean blank & 0.005 & 0.020 & 0.011 & 0.261 \\
Method detection limit & 0.02 & 0.06 & 0.03 & 0.8
\end{tabular}

$\underline{\text { Standard reference material }}$

$1566 \mathrm{a}$-Replicate 1

1566a-Replicate 2

Certified value

Range

DOLT-2-Replicate 2

DOLT-2-Replicate 3

Certified value

Range
DOLT-2-Replicate 1

3.79

3.90

4.15

$\pm 0.38$

18.3

17.3

18.2

20.8

$\pm 0.5$

Matrix spike results

Amount spiked

755USGS-1 (KF1905WAL8030)

755USGS-1 + Spike 1

Amount recovered

Percent recovery

Amount spiked

755USGS-1 (KF1905WAL8030)

755USGS-1 + Spike 2

Amount recovered

Percent recovery

Amount spiked

755USGS-10 (SP1505WAL8004)

755USGS-10 + Spike 1

Amount recovered

Percent recovery

$\begin{array}{cc}5.00 & 5.00 \\ 5.01 & 48.8 \\ 9.62 & 53.8 \\ 4.61 & 5.00 \\ 92 & 100\end{array}$

50.0

5.01

46.0

41.0

82

0.500
4.72
5.32
0.60

120
62.4

56.2

66.3

$\pm 4.3$

25.5

24.8

23.1

25.8

$\pm 1.1$

50.0

48.8

93.1

44.3

89

0.500

47.8

50.2

2.40

SL
925

710

830

$\pm 57$

$\pm .014 \quad \pm 57$

$\begin{array}{rr}0.195 & 76.9 \\ 0.206 & 73.9 \\ 0.130 & 71.2 \\ 0.22 & 85.8 \\ \pm 0.02 & \pm 22.5\end{array}$

73.9

71.2

85.8

$\pm 22.5$
5.00

0.156

5.13

4.97

99

50.0

0.156

46.2

46.0

92

0.500

0.052

0.531

0.479

96
50.0

92.9

135

41.8

84

5.00

92.9

98.2

5.30

106

0.500

90.7

94.3

3.60

SL 
Table 11.--Quality-assurance data for the analysis of cadmium, copper, lead, and zinc in liver tissue of walleye, smallmouth bass, and rainbow trout. Inductively coupled plasma mass spectography (ICP/MS) analysis from Battelle Marine Science Laboratory, Sequim, Washington.--Continued

\begin{tabular}{lcccc}
\hline & \multicolumn{3}{c}{ Concentrations, in micrograms per gram, dry weight } \\
\cline { 2 - 5 } Sample description & Cadmium & Copper & Lead & Zinc \\
\hline Amount spiked & 50.0 & 50.0 & 50.0 & 50.0 \\
755USGS-10 (SP1505WAL8004) & 4.72 & 47.8 & 0.052 & 90.7 \\
755USGS-20 + Spike 2 & 46.6 & 97.3 & 45.6 & 144 \\
Amount recovered & 41.9 & 49.5 & 45.5 & 53.0 \\
Percent recovery & 84 & 99 & 91 & 106 \\
& & & & 5.00 \\
Amount spiked & 5.00 & 5.00 & 5.00 & 101 \\
755USGS-29 (SP1903WAL8059) & 15.7 & 51.1 & 0.094 & 101 \\
755USGS-29 + Spike 1 & 19.4 & 55.4 & 4.59 & 0.00 \\
Amount recovered & 3.70 & 4.30 & 4.50 & SL \\
Percent recovery & SL & 86 & 90 & 500 \\
\hline
\end{tabular}

${ }^{1}$ Value used to blank-subtract data.

${ }^{2}$ Analyte reported below reporting limit.

${ }^{3}$ Not detected at or above detection limit shown. 


\section{REFERENCES CITED}

Bortleson, G.C., Cox, S.E., Munn, M.D., Schumaker, R.J., Block, E.K., Bucy, L.R., and Cornelius, S.B., 1994, Sediment-quality assessment of Franklin D. Roosevelt Lake and the upstream reach of the Columbia River, Washington, 1992: U.S. Geological Survey Open-File Report 94-315, 130 p., 1 pl.

Crecelius, E., Apts, C., Bingler, L., Cotter, O., Kiesser, S., and Sanders, R., 1993, Analysis of marine sediment and bivalve tissue by $\mathrm{X}$-ray fluorescence, atomic absorption, and inductively coupled plasma mass spectrometry, in sampling and analytical methods of the national status and trends program-National Benthic Surveillance and Mussel Watch Projects, 1984-1992, vol III, Comprehensive descriptions of elemental analytical methods (Lauenstein, G.G., and Cantillo, A.Y., eds): NOAA Technical Memorandum NOS ORCA 71, p. III.187 to III.212.

Lowe, T.P., May, T.W., Brumbaugh, W.G., and Kane, D.A., 1985, National Contaminant Biomonitoring Program-Concentrations of seven elements in freshwater fish, 1978-1981: Archives of Environmental Contamination and Toxicology, v. 14, p. $363-388$.

McDowell, A.C., and Griffith., J.R., 1993, Retrospective analysis on the fishery of Lake Roosevelt, Wash., Final Report 1993: Wellpinit, Wash., Spokane Tribal Fish and Wildlife Center, $68 \mathrm{p}$
Persaud, D., Jaagumagi, R., and Hayton, A., 1991, The Provincial sediment-quality guidelines: Ontario Ministry of Environment and Energy, Water Resource Branch, 23 p.

Serdar, D. 1993, Retrospective analysis of toxic contaminants in Lake Roosevelt, Draft No. 2: Olympia, Wash., Evergreen State College, 89 p. plus appendices.

U.S. Environmental Protection Agency, 1991a Determination of mercury in tissues by cold vapor atomic absorption spectrometry: Method 245.6 (Revision 2.3), Environmental Monitoring Systems Laboratory, Office of Research and Development, U.S. Environmental Protection Agency, Cincinnati, Ohio,

1991b, Sample preparation procedure for spectrochemical determination of total recoverable elements in biological tissue: Method 200.3 (Revision 1.0), Environmental Monitoring Systems Laboratory, Office of Research and Development, U.S. Environmental Protection Agency, Cincinnati, Ohio,

1992, National study of chemical residues in fish, Volume I: United State Environmental Protection Agency, Office of Science and Technology, EPA 823-R-92-008a, 166 p. plus appendices.

1993, Guidance for assessing chemical contaminant data for use in fish advisories, Volume 1, Fish sampling and analysis: United State Environmental Protection Agency, Office of Water, EPA 823-R-93-002, unpaginated. 
Appendix A.--Summary of Parameters on Individual Fish Collected During the Lake Roosevelt Study 
[USGS, U.S. Geological Survey; mm, millimeter; M, male; F, female; U, unknown; yrs, years; Kettle, Columbia River and Lake Roosevelt near Kettle Falls; Spokane, mid reach of Lake Roosevelt and lower Spokane River; Sanpoil, Sanpoil River embayment; size class 1, 10 to 12 inches; 2, greater than 13 to 16 inches; 3, greater than 16 to 19 inches; and 4, greater than 19 to 22 inches--, not applicable]

\begin{tabular}{|c|c|c|c|c|c|c|c|c|c|c|c|c|}
\hline Species & Site & $\begin{array}{l}\text { USGS } \\
\text { sample } \\
\text { code }\end{array}$ & $\begin{array}{l}\text { Size } \\
\text { class }\end{array}$ & $\begin{array}{l}\text { Repli- } \\
\text { cate }\end{array}$ & $\begin{array}{l}\text { Total } \\
\text { length } \\
(\mathrm{mm})\end{array}$ & $\begin{array}{l}\text { Total } \\
\text { weight } \\
\text { (grams) }\end{array}$ & $\begin{array}{l}\text { Gender } \\
\text { M-F-U }\end{array}$ & $\begin{array}{l}\text { Fillet } \\
\text { weight } \\
\text { (grams) }\end{array}$ & $\begin{array}{l}\text { Liver } \\
\text { weight } \\
\text { (grams) }\end{array}$ & $\begin{array}{l}\text { Age } \\
\text { (yrs) }\end{array}$ & $\begin{array}{l}\text { USGS } \\
\text { sample } \\
\text { code }\end{array}$ & $\begin{array}{l}\text { Fillet } \\
\text { weight } \\
\text { (grams) }\end{array}$ \\
\hline \multirow[t]{8}{*}{ Walleye } & \multirow[t]{8}{*}{ Kettle } & FDRKF1905- & \multirow[t]{8}{*}{1} & 1 & 315 & 257 & $\mathrm{U}$ & 44 & 1.4 & 1 & -- & -- \\
\hline & & \multirow[t]{7}{*}{ WAF8030 } & & 2 & 286 & 182 & U & 32 & 2.8 & 1 &.- & -- \\
\hline & & & & 3 & 330 & 303 & U & 50 & 1.2 & 2 & -- & -. \\
\hline & & & & 4 & 315 & 247 & U & 46 & 4.6 & 2 & -- & - \\
\hline & & & & 5 & 318 & 258 & U & 31 & 2 & 1 & -- & -- \\
\hline & & & & 6 & 322 & 261 & $\mathrm{U}$ & 34 & 2.6 & 2 & -- & -- \\
\hline & & & & 7 & 320 & 241 & U & 47 & 3.3 & 2 & -- & -- \\
\hline & & & & 8 & 334 & 342 & U & 34 & 1.7 & 1 & -- & -- \\
\hline \multicolumn{2}{|c|}{ Sample mean } & & & & 318 & 261 & & 39 & 2.6 & 1.5 & & \\
\hline \multirow[t]{8}{*}{ Walleye } & \multirow[t]{8}{*}{ Kettle } & FDRKFI605- & \multirow[t]{9}{*}{2} & 1 & 362 & 350 & M & 58 & 4.6 & 2 & F1014.1 & 163 \\
\hline & & WAF8014 & & 2 & 347 & 314 & M & 40 & 3.6 & 2 & F1014.2 & 237 \\
\hline & & & & 3 & 374 & 444 & $M$ & 71 & 4.4 & 2 & F1014.3 & 365 \\
\hline & & & & 4 & 343 & 354 & M & 44 & 3.4 & 2 & F1014.4 & .447 \\
\hline & & & & 5 & 343 & 314 & $\mathrm{U}$ & 56 & 4.3 & 2 & F1014.5 & $\begin{array}{ll}5 \quad 48 \\
\end{array}$ \\
\hline & & & & 6 & 404 & 560 & M & 63 & 6.3 & 3 & F1014.6 & 667 \\
\hline & & & & 7 & 381 & 409 & $\mathrm{U}$ & 66 & 3.7 & 3 & F1014.7 & .752 \\
\hline & & & & 8 & 365 & 401 & $\mathrm{U}$ & 46 & 4.7 & 2 & F1014.8 & 833 \\
\hline \multicolumn{2}{|c|}{ Sample mean } & & & & 365 & 393 & & 55 & 4.3 & 2.3 & & \\
\hline \multirow[t]{8}{*}{ Walleye } & \multirow[t]{8}{*}{ Kettle } & FDRKF1605- & \multirow[t]{8}{*}{2} & 1 & 399 & 541 & $\mathrm{U}$ & 79 & 6.7 & 3 & -- & -- \\
\hline & & WAF8019 & & 2 & 407 & 517 & M & 60 & 5 & 4 & -- & -- \\
\hline & & & & 3 & 401 & 537 & M & 60 & 6.7 & 5 & -- & -- \\
\hline & & & & 4 & 380 & 464 & $\mathrm{U}$ & 56 & 3.7 & 4 & -- & -- \\
\hline & & & & 5 & 370 & 414 & F & 72 & 5 & 2 & -- & -- \\
\hline & & & & 6 & 387 & 512 & $\mathrm{U}$ & 59 & 7.3 & 4 & -- & $-\cdot$ \\
\hline & & & & 7 & 389 & 500 & M & 66 & 6.3 & 4 & -- & -- \\
\hline & & & & 8 & 378 & 444 & $\mathrm{U}$ & 47 & 4 & 5 & -- & - \\
\hline \multicolumn{2}{|c|}{ Sample mean } & & & & 389 & 491 & & 60 & 5.4 & 3.9 & & \\
\hline \multirow[t]{8}{*}{ Walleye } & \multirow[t]{8}{*}{ Kettle } & FDRKF1605- & \multirow[t]{8}{*}{2} & 1 & 345 & 329 & $\mathbf{M}$ & 62 & 2.9 & 2 & -- & -- \\
\hline & & WAF8015 & & 2 & 373 & 484 & M & 51 & 3.8 & 2 & -- & -- \\
\hline & & & & 3 & 397 & 543 & $\mathrm{~F}$ & 103 & 4.7 & 3 & -- & -- \\
\hline & & & & 4 & 390 & 440 & M & 41 & 5.1 & 4 & -- & -- \\
\hline & & & & 5 & 378 & 400 & M & 66 & 5.9 & 3 & -- & -- \\
\hline & & & & 6 & 400 & 555 & M & 85 & 6.3 & 5 & -- & -- \\
\hline & & & & 7 & 399 & 510 & $\mathrm{M}$ & 84 & 6.4 & 2 & -- & - \\
\hline & & & & 8 & 360 & 370 & $\mathbf{M}$ & 39 & 4.1 & 2 & -- & -- \\
\hline Sample $n$ & & & & & 380 & $\overline{454}$ & & 67 & 5.2 & 2.9 & & \\
\hline
\end{tabular}


Appendix A.--Summary of parameters on individual fish collected during the Lake Roosevelt study--Continued

\begin{tabular}{|c|c|c|c|c|c|c|c|c|c|c|c|c|}
\hline Species & Site & $\begin{array}{l}\text { USGS } \\
\text { sample } \\
\text { code }\end{array}$ & $\begin{array}{l}\text { Size } \\
\text { class }\end{array}$ & $\begin{array}{l}\text { Repli- } \\
\text { cate }\end{array}$ & $\begin{array}{l}\text { Total } \\
\text { length } \\
(\mathrm{mm})\end{array}$ & $\begin{array}{l}\text { Total } \\
\text { weight } \\
\text { (grams) }\end{array}$ & $\begin{array}{l}\text { Gender } \\
\mathrm{M}-\mathrm{F}-\mathrm{U}\end{array}$ & $\begin{array}{l}\text { Fillet } \\
\text { weight } \\
\text { (grams) }\end{array}$ & $\begin{array}{l}\text { Liver } \\
\text { weight } \\
\text { (grams) }\end{array}$ & $\begin{array}{l}\text { Age } \\
\text { (yrs) }\end{array}$ & $\begin{array}{l}\text { USGS } \\
\text { sample } \\
\text { code }\end{array}$ & $\begin{array}{l}\text { Fillet } \\
\text { weight } \\
\text { (grams) }\end{array}$ \\
\hline \multirow[t]{8}{*}{ Walleye } & \multirow[t]{8}{*}{ Kettle } & \multirow{8}{*}{$\begin{array}{l}\text { FDRKF1906- } \\
\text { WAF8055 }\end{array}$} & \multirow[t]{8}{*}{2} & 1 & 395 & 495 & $\mathbf{F}$ & 79 & 3.3 & 4 & -- & -- \\
\hline & & & & 2 & 340 & 351 & $\mathrm{U}$ & 39 & 4.1 & 2 & $\cdots$ & - \\
\hline & & & & 3 & 355 & 344 & $\mathrm{U}$ & 42 & 3.9 & 2 & $\cdots$ & -- \\
\hline & & & & 4 & 395 & 464 & $\mathrm{U}$ & 90 & 1.3 & 3 & -- & -- \\
\hline & & & & 5 & 370 & 384 & $\mathrm{U}$ & 36 & 2.5 & 2 & -- & -- \\
\hline & & & & 6 & 337 & 296 & $\mathrm{U}$ & 40 & 3 & 2 & -- & -- \\
\hline & & & & 7 & 376 & 452 & $\mathbf{U}$ & 95 & 5 & 2 & -- & -- \\
\hline & & & & 8 & 350 & 298 & $\mathrm{U}$ & 39 & 2 & 2 & -- & -- \\
\hline \multicolumn{2}{|c|}{ Sample mean } & & & & 365 & 386 & & 54 & 3.1 & 2.4 & & \\
\hline \multirow[t]{8}{*}{ Walleye } & \multirow[t]{8}{*}{ Kettle } & \multirow{8}{*}{$\begin{array}{l}\text { FDRKF1906- } \\
\text { WAF8057 }\end{array}$} & \multirow[t]{8}{*}{2} & 1 & 382 & 473 & $\mathbf{F}$ & 71 & 3.4 & 2 & -- & -- \\
\hline & & & & 2 & 405 & 523 & $\mathbf{F}$ & 107 & 3.3 & 4 & - & -- \\
\hline & & & & 3 & 350 & 337 & $\mathbf{U}$ & 55 & 2 & 2 & -- & - \\
\hline & & & & 4 & 355 & 288 & $F$ & 57 & 1.8 & 3 & -- & -- \\
\hline & & & & 5 & 400 & 549 & M & 82 & 3.8 & 3 & -- & -- \\
\hline & & & & 6 & 371 & 412 & $F$ & 82 & 3.6 & 3 & -- & -- \\
\hline & & & & 7 & 390 & 470 & $\mathrm{U}$ & 74 & 4.5 & 4 & -- & -- \\
\hline & & & & 8 & 380 & 461 & $\mathrm{~F}$ & 71 & 3.2 & 3 & -- & -- \\
\hline \multicolumn{3}{|c|}{ Sample mean } & & & 379 & 439 & & 75 & 3.2 & 3.0 & & \\
\hline \multirow[t]{8}{*}{ Walleye } & \multirow[t]{8}{*}{ Kettle } & \multirow{8}{*}{$\begin{array}{l}\text { FDRKF1906- } \\
\text { WAF8058 }\end{array}$} & \multirow[t]{8}{*}{2} & 1 & 365 & 409 & $\mathrm{U}$ & 62 & 3.5 & 2 & -- & -- \\
\hline & & & & 2 & 400 & 481 & M & 105 & 4.4 & 3 & -- & -- \\
\hline & & & & 3 & 365 & 393 & M & 54 & 3.7 & 4 & -- & -- \\
\hline & & & & 4 & 370 & 454 & $F$ & 87 & 5.5 & 3 & -- & - \\
\hline & & & & 5 & 351 & 369 & $F$ & 50 & 2.4 & 2 & -- & -- \\
\hline & & & & 6 & 345 & 309 & $\mathrm{U}$ & 36 & 2.7 & 2 & -- & -- \\
\hline & & & & 7 & 346 & 340 & $\mathbf{F}$ & 46 & 2.2 & 2 & -- & -- \\
\hline & & & & 8 & 380 & 374 & $\mathrm{U}$ & 72 & 2.3 & 3 & -- & -- \\
\hline \multicolumn{3}{|c|}{ Sample mean } & & & 365 & 391 & & 64 & 3.3 & 2.6 & & \\
\hline \multirow[t]{8}{*}{ Walleye } & \multirow[t]{8}{*}{ Kettle } & FDRKF1605- & \multirow[t]{8}{*}{3} & 1 & 426 & 594 & M & 58 & 6.7 & 6 & -- & $\cdots$ \\
\hline & & WAF8016 & & 2 & 453 & 726 & M & 120 & 7.5 & 5 & -- & -- \\
\hline & & & & 3 & 391 & 498 & M & 60 & 4 & 4 & -- & -- \\
\hline & & & & 4 & 424 & 508 & $\mathrm{M}$ & 87 & 5.4 & 3 & -- & -- \\
\hline & & & & 5 & 460 & 797 & $\mathbf{M}$ & 135 & 8.6 & 2 & -- & -- \\
\hline & & & & 6 & 448 & 722 & $\mathrm{M}$ & 82 & 9 & 3 & -- & -- \\
\hline & & & & 7 & 415 & 480 & $\mathrm{M}$ & 79 & 4.4 & 5 & -- & -- \\
\hline & & & & 8 & 414 & 555 & $\mathbf{M}$ & 58 & 6.4 & 4 & -- & -- \\
\hline \multicolumn{3}{|c|}{ Sample mean } & & & 429 & 610 & & 89 & 65 & 4.0 & & \\
\hline
\end{tabular}


Appendix A.--Summary of parameters on individual fish collected during the Lake Roosevelt study--Continued

\begin{tabular}{|c|c|c|c|c|c|c|c|c|c|c|c|c|}
\hline Species & Site & $\begin{array}{l}\text { USGS } \\
\text { sample } \\
\text { code }\end{array}$ & $\begin{array}{l}\text { Size } \\
\text { class }\end{array}$ & $\begin{array}{l}\text { Repli- } \\
\text { cate }\end{array}$ & $\begin{array}{l}\text { Total } \\
\text { length } \\
(\mathrm{mm})\end{array}$ & $\begin{array}{l}\text { Total } \\
\text { weight } \\
\text { (grams) }\end{array}$ & $\begin{array}{l}\text { Gender } \\
\text { M-F-U }\end{array}$ & $\begin{array}{l}\text { Fillet } \\
\text { weight } \\
\text { (grams) }\end{array}$ & $\begin{array}{l}\text { Liver } \\
\text { weight } \\
\text { (grams) }\end{array}$ & $\begin{array}{l}\text { Age } \\
\text { (yrs) }\end{array}$ & $\begin{array}{l}\text { USGS } \\
\text { sample } \\
\text { code }\end{array}$ & $\begin{array}{l}\text { Fillet } \\
\text { weight } \\
\text { (grams) }\end{array}$ \\
\hline \multirow[t]{8}{*}{ Walleye } & \multirow[t]{8}{*}{ Kettle } & \multirow{8}{*}{$\begin{array}{l}\text { FDRKF1605- } \\
\text { WAF8017 }\end{array}$} & \multirow[t]{8}{*}{3} & 1 & 435 & 655 & M & 113 & 6.9 & 4 & -- & -- \\
\hline & & & & 2 & 410 & 506 & M & 42 & 4.9 & 5 & -- & -- \\
\hline & & & & 3 & 412 & 575 & M & 66 & 5.3 & 6 & -- &.- \\
\hline & & & & 4 & 458 & 874 & M & 111 & 8.1 & 4 & -- & -- \\
\hline & & & & 5 & 444 & 562 & $\mathrm{~F}$ & 65 & 5.1 & 4 & -- & -- \\
\hline & & & & 6 & 420 & 548 & M & 62 & 5 & 4 & -- & -- \\
\hline & & & & 7 & 430 & 601 & $\mathrm{~F}$ & 83 & 5.3 & 3 & -- & -- \\
\hline & & & & 8 & 460 & 879 & $\mathrm{M}$ & 85 & 8.2 & 7 & -- & -- \\
\hline \multicolumn{2}{|c|}{ Sample mean } & & & & 434 & 650 & & 73 & 6.0 & 4.6 & & \\
\hline \multirow[t]{8}{*}{ Walleye } & \multirow[t]{8}{*}{ Kettle } & FDRKF1605- & \multirow[t]{8}{*}{3} & 1 & 455 & 813 & $\mathbf{M}$ & 125 & 9.4 & 5 & -- & -- \\
\hline & & \multirow[t]{7}{*}{ WAF8018 } & & 2 & 419 & 543 & M & 59 & 5 & 3 & - & -- \\
\hline & & & & 3 & 470 & 800 & M & 110 & 7.9 & 6 & -- & -- \\
\hline & & & & 4 & 424 & 618 & $\mathrm{U}$ & 85 & 5.8 & 4 & -- & -- \\
\hline & & & & 5 & 432 & 710 & $\mathrm{U}$ & 106 & 6.7 & 4 & -- & -- \\
\hline & & & & 6 & 410 & 489 & M & 49 & 4.8 & 4 & -- & -- \\
\hline & & & & 7 & 416 & 544 & $F$ & 81 & 5.4 & 4 & -- & -- \\
\hline & & & & 8 & 413 & 565 & $\mathbf{M}$ & 66 & 6 & 3 & -- & -. \\
\hline \multicolumn{2}{|c|}{ Sample mean } & & & & 430 & 635 & & 79 & 5.9 & 4.1 & & \\
\hline \multirow[t]{8}{*}{ Walleye } & \multirow[t]{8}{*}{ Kettle } & FDRKF1906- & \multirow[t]{8}{*}{3} & 1 & 452 & 668 & $\mathbf{M}$ & 82 & 6.3 & 6 & -- & -. \\
\hline & & \multirow[t]{7}{*}{ WAF8056 } & & 2 & 435 & 626 & $\mathrm{~F}$ & 111 & 6 & 4 & -. & - \\
\hline & & & & 3 & 455 & 711 & M & 94 & 3.5 & 6 & -- & -- \\
\hline & & & & 4 & 461 & 680 & $\mathrm{~F}$ & 127 & 5.3 & 5 & -- & -- \\
\hline & & & & 5 & 435 & 619 & $\mathrm{~F}$ & 63 & 4.7 & 4 & - & -- \\
\hline & & & & 6 & 430 & 701 & $\mathrm{~F}$ & 87 & 3.9 & 4 & -- & -- \\
\hline & & & & 7 & 415 & 578 & $\mathrm{~F}$ & 115 & 3.4 & 3 & -- & -- \\
\hline & & & & 8 & 420 & 615 & $\mathrm{U}$ & 76 & 3 & 2 & -- & -- \\
\hline \multicolumn{3}{|c|}{ Sample mean } & & & 438 & 650 & & 96 & 4.3 & 4.3 & & \\
\hline \multirow[t]{8}{*}{ Walleye } & \multirow[t]{8}{*}{ Kettle } & FDRKF1605- & \multirow[t]{8}{*}{4} & 1 & 483 & 755 & $\mathrm{~F}$ & 109 & 9.4 & 5 & - & -- \\
\hline & & WAF8021 & & 2 & 523 & 1,283 & $\mathrm{~F}$ & 133 & 10.8 & 5 & -- & -- \\
\hline & & & & 3 & 501 & 1,000 & $\mathrm{~F}$ & 158 & 13.2 & 5 & -- & -- \\
\hline & & & & 4 & 488 & 955 & $\mathrm{U}$ & 109 & 10.3 & 4 & -- & -- \\
\hline & & & & 5 & 487 & 657 & $\mathrm{~F}$ & 74 & 5 & 5 & - & -- \\
\hline & & & & 6 & 520 & 1,287 & $\mathrm{~F}$ & 137 & 9.8 & 7 & -- & -- \\
\hline & & & & 7 & 515 & 1,063 & $F$ & 175 & 10.3 & 5 & -- & -- \\
\hline & & & & 8 & 510 & 1,373 & $\mathrm{~F}$ & 163 & 15.7 & 4 & -- & -- \\
\hline \multicolumn{2}{|c|}{ Sample mean } & & & & 503 & 1,047 & & 136 & 10.7 & 5.0 & & \\
\hline
\end{tabular}


Appendix A.--Summary of parameters on individual fish collected during the Lake Roosevelt study--Continued

\begin{tabular}{|c|c|c|c|c|c|c|c|c|c|c|c|c|}
\hline Species & Site & $\begin{array}{l}\text { USGS } \\
\text { sample } \\
\text { code }\end{array}$ & $\begin{array}{l}\text { Size } \\
\text { class }\end{array}$ & $\begin{array}{l}\text { Repli- } \\
\text { cate }\end{array}$ & $\begin{array}{l}\text { Total } \\
\text { length } \\
(\mathrm{mm})\end{array}$ & $\begin{array}{l}\text { Total } \\
\text { weight } \\
\text { (grams) }\end{array}$ & $\begin{array}{l}\text { Gender } \\
\text { M-F-U }\end{array}$ & $\begin{array}{l}\text { Fillet } \\
\text { weight } \\
\text { (grams) }\end{array}$ & $\begin{array}{l}\text { Liver } \\
\text { weight } \\
\text { (grams) }\end{array}$ & $\begin{array}{l}\text { Age } \\
\text { (yrs) }\end{array}$ & $\begin{array}{l}\text { USGS } \\
\text { sample } \\
\text { code }\end{array}$ & $\begin{array}{l}\text { Fillet } \\
\text { weight } \\
\text { (grams) }\end{array}$ \\
\hline \multirow[t]{8}{*}{ Walleye } & \multirow[t]{8}{*}{ Spokane } & FDRSP1505- & \multirow[t]{8}{*}{1} & 1 & 310 & 216 & $\mathbf{M}$ & 33 & 2.2 & 1 & -- & -- \\
\hline & & \multirow[t]{7}{*}{ WAF8003 } & & 2 & 306 & 219 & $\mathrm{U}$ & 32 & 0.8 & 1 & -- & -- \\
\hline & & & & 3 & 290 & 180 & $\mathbf{M}$ & 32 & 2 & 1 & -- & -- \\
\hline & & & & 4 & 304 & 210 & $\mathrm{U}$ & 30 & 1.6 & 1 & -- & $\ldots$ \\
\hline & & & & 5 & 308 & 220 & $\mathbf{M}$ & 38 & 2.7 & 1 & -- & -- \\
\hline & & & & 6 & 315 & 222 & $\mathrm{U}$ & 33 & 1.6 & 2 & -- &.- \\
\hline & & & & 7 & 298 & 194 & $\mathrm{U}$ & 36 & 2.1 & 1 & -- &.- \\
\hline & & & & 8 & 293 & 188 & $\mathrm{U}$ & 28 & 0.8 & 1 & -. &.- \\
\hline \multicolumn{2}{|c|}{ Sample mean } & & & & 303 & 206 & & 33 & 1.7 & 1.1 & & \\
\hline \multirow[t]{8}{*}{ Walleye } & \multirow[t]{8}{*}{ Spokane } & \multirow{8}{*}{$\begin{array}{l}\text { FDRSP1505- } \\
\text { WAF8004 }\end{array}$} & \multirow[t]{8}{*}{1} & 1 & 281 & 159 & $\mathrm{U}$ & 22 & 1.5 & 1 & -- & -- \\
\hline & & & & 2 & 310 & 217 & $\mathrm{U}$ & 41 & 2.8 & 1 & -- & -- \\
\hline & & & & 3 & 325 & 268 & $\mathrm{U}$ & 42 & 1.8 & 2 & -- & -- \\
\hline & & & & 4 & 318 & 244 & $\mathrm{U}$ & 48 & 3.3 & 1 & -- & -- \\
\hline & & & & 5 & 306 & 201 & $\mathrm{U}$ & 28 & 0.9 & 1 & -- & -- \\
\hline & & & & 6 & 312 & 218 & $\mathrm{U}$ & 35 & 2.1 & 1 & -- & -- \\
\hline & & & & 7 & 304 & 211 & $\mathrm{U}$ & 34 & 1 & 1 & -- & -- \\
\hline & & & & 8 & 318 & 235 & $\mathbf{M}$ & 42 & 2.2 & 1 & -- & -- \\
\hline \multicolumn{2}{|c|}{ Sample mean } & & & & 309 & 219 & & 39 & 2.0 & 1.1 & & \\
\hline \multirow[t]{8}{*}{ Walleye } & \multirow[t]{8}{*}{ Spokane } & FDRSP1505- & \multirow[t]{8}{*}{1} & 1 & 315 & 219 & $\mathbf{M}$ & 31 & 1.9 & 2 & -- & -- \\
\hline & & \multirow[t]{7}{*}{ WAF8008 } & & 2 & 276 & 156 & $\mathbf{M}$ & 34 & 1.5 & 1 & -- & -- \\
\hline & & & & 3 & 310 & 258 & $\mathbf{M}$ & 34 & 1 & 1 & -- & -- \\
\hline & & & & 4 & 323 & 237 & $\mathbf{M}$ & 45 & 1.6 & 2 & -- & -- \\
\hline & & & & 5 & 325 & 292 & $\mathbf{M}$ & 37 & 2.5 & 1 & -. & -- \\
\hline & & & & 6 & 310 & 231 & $\mathrm{U}$ & 45 & 1.5 & 2 & -- & -- \\
\hline & & & & 7 & 330 & 282 & $\mathbf{M}$ & 30 & 1.7 & 2 & -- & -- \\
\hline & & & & 8 & 299 & 187 & M & 36 & 1.7 & 1 & -- & -- \\
\hline \multicolumn{2}{|c|}{ Sample mean } & & & & 311 & 233 & & 37 & 1.6 & 1.5 & & \\
\hline \multirow[t]{8}{*}{ Walleye } & \multirow[t]{8}{*}{ Spokane } & FDRSP1706- & \multirow[t]{8}{*}{1} & 1 & 326 & 286 & $\mathrm{U}$ & 43 & 2.9 & 2 & -- & -- \\
\hline & & WAF8051 & & 2 & 275 & 152 & $\mathrm{U}$ & 18 & 2.1 & 1 & -- & -- \\
\hline & & & & 3 & 325 & 258 & $\mathrm{U}$ & 36 & 2.1 & 2 & -- & -- \\
\hline & & & & 4 & 305 & 234 & $\mathrm{U}$ & 25 & 3 & 2 & -- & -- \\
\hline & & & & 5 & 323 & 260 & $\mathrm{U}$ & 38 & 2.1 & 2 & -- & -- \\
\hline & & & & 6 & 305 & 216 & $\mathrm{U}$ & 31 & 1.7 & 2 & -- & -- \\
\hline & & & & 7 & 320 & 251 & $\mathrm{U}$ & 41 & 1.5 & 2 & -- & -- \\
\hline & & & & 8 & 305 & 222 & $U$ & 35 & 3.8 & 2 & -- & -- \\
\hline \multicolumn{2}{|c|}{ Sample mean } & & & & 311 & 235 & & 32 & 2.3 & 1.9 & & \\
\hline
\end{tabular}


Appendix A.--Summary of parameters on individual fish collected during the Lake Roosevelt study--Continued

\begin{tabular}{|c|c|c|c|c|c|c|c|c|c|c|c|c|}
\hline Species & Site & $\begin{array}{l}\text { USGS } \\
\text { sample } \\
\text { code }\end{array}$ & $\begin{array}{l}\text { Size } \\
\text { class }\end{array}$ & $\begin{array}{l}\text { Repli- } \\
\text { cate }\end{array}$ & $\begin{array}{l}\text { Total } \\
\text { length } \\
(\mathrm{mm})\end{array}$ & $\begin{array}{l}\text { Total } \\
\text { weight } \\
\text { (grams) }\end{array}$ & $\begin{array}{l}\text { Gender } \\
\text { M-F-U }\end{array}$ & $\begin{array}{l}\text { Fillet } \\
\text { weight } \\
\text { (grams) }\end{array}$ & $\begin{array}{l}\text { Liver } \\
\text { weight } \\
\text { (grams) }\end{array}$ & $\begin{array}{l}\text { Age } \\
\text { (yrs) }\end{array}$ & $\begin{array}{ll}\text { USGS } & F \\
\text { sample } & w \\
\text { code } & (g\end{array}$ & $\begin{array}{l}\text { Fillet } \\
\text { weight } \\
\text { (grams) }\end{array}$ \\
\hline \multirow[t]{8}{*}{ Walleye } & \multirow[t]{8}{*}{ Spokane } & FDRSPI906- & \multirow[t]{8}{*}{1} & 1 & 330 & 276 & $U$ & 34 & 3.5 & 2 & -- & $\ldots$ \\
\hline & & \multirow[t]{7}{*}{ WAF8052 } & & 2 & 303 & 195 & $\mathrm{U}$ & 36 & 1.4 & 1 & -- & -- \\
\hline & & & & 3 & 330 & 309 & $\mathrm{U}$ & 30 & 3.8 & 2 & -- & -- \\
\hline & & & & 4 & 296 & 185 & $\mathrm{U}$ & 35 & 1.8 & 1 & -- & -- \\
\hline & & & & 5 & 310 & 231 & $\mathrm{U}$ & 32 & 2.5 & 2 & - & -- \\
\hline & & & & 6 & 322 & 228 & $\mathrm{U}$ & 72 & 1.4 & 2 & - & -- \\
\hline & & & & 7 & 325 & 272 & $\mathrm{U}$ & 40 & 0.1 & 2 & -. & -- \\
\hline & & & & 8 & 344 & 312 & $\mathrm{U}$ & 61 & 3.4 & 2 &.- & -- \\
\hline \multicolumn{2}{|c|}{ Sample mean } & & & & 320 & 251 & & 44 & 2.1 & 1.8 & & \\
\hline \multirow[t]{8}{*}{ Walleye } & \multirow[t]{8}{*}{ Spokane } & \multirow{8}{*}{$\begin{array}{l}\text { FDRSP1505- } \\
\text { WAF8005 }\end{array}$} & \multirow[t]{8}{*}{2} & 1 & 365 & 368 & $\mathbf{M}$ & 53 & 2.2 & 2 & -- & -- \\
\hline & & & & 2 & 356 & 360 & $\mathbf{M}$ & 58 & 5.6 & 2 & - & -- \\
\hline & & & & 3 & 360 & 389 & $\mathbf{M}$ & 57 & 2.9 & 2 & -- & - \\
\hline & & & & 4 & 359 & 342 & M & 64 & 4.3 & 2 & -- & -- \\
\hline & & & & 5 & 350 & 321 & $\mathbf{M}$ & 43 & 2 & 2 & -- & - \\
\hline & & & & 6 & 378 & 428 & $\mathbf{M}$ & 71 & 5 & 3 & -- & -- \\
\hline & & & & 7 & 340 & 331 & $\mathbf{M}$ & 47 & 1.3 & 1 & -- & -- \\
\hline & & & & 8 & 368 & 396 & M & 65 & 4.3 & 2 & -- & -- \\
\hline \multicolumn{2}{|c|}{ Sample mean } & & & & 360 & 367 & & 58 & 3.6 & 2.0 & & \\
\hline \multirow[t]{8}{*}{ Walleye } & \multirow[t]{8}{*}{ Spokane } & \multirow{8}{*}{$\begin{array}{l}\text { FDRSP1505- } \\
\text { WAF8006 }\end{array}$} & \multirow[t]{8}{*}{2} & 1 & 341 & 290 & $\mathbf{M}$ & 38 & 1.8 & 2 & F1006.1 & 29 \\
\hline & & & & 2 & 356 & 338 & $\mathrm{M}$ & 51 & 4.4 & 2 & F1006.2 & 248 \\
\hline & & & & 3 & 345 & 279 & M & 42 & 2.4 & 2 & F1006.3 & 26 \\
\hline & & & & 4 & 362 & 338 & $\mathbf{M}$ & 60 & 3.3 & 2 & F1006.4 & 450 \\
\hline & & & & 5 & 358 & 358 & $\mathrm{U}$ & 66 & 3.8 & 1 & F1006.5 & 552 \\
\hline & & & & 6 & 351 & 342 & $\mathrm{U}$ & 41 & 3 & 2 & F1006.6 & 534 \\
\hline & & & & 7 & 346 & 266 & $\mathrm{U}$ & 46 & 2.4 & 2 & F1006.7 & $7 \quad 45$ \\
\hline & & & & 8 & 366 & 432 & $\mathrm{U}$ & 70 & 2.1 & 2 & F1006.8 & 847 \\
\hline \multicolumn{2}{|c|}{ Sample mean } & & & & 353 & 330 & & 54 & 3.1 & 1.9 & & \\
\hline \multirow[t]{8}{*}{ Walleye } & \multirow[t]{8}{*}{ Spokane } & FDRSP1505- & \multirow[t]{8}{*}{2} & 1 & 355 & 335 & $\mathrm{U}$ & 40 & 1.2 & 2 & $\ldots$ & -- \\
\hline & & WAF8007 & & 2 & 340 & 269 & $\mathrm{U}$ & 53 & 3.8 & 2 & -- & -- \\
\hline & & & & 3 & 355 & 370 & $\mathrm{U}$ & 55 & 2.2 & 2 & -- & -- \\
\hline & & & & 4 & 356 & 337 & $\mathbf{M}$ & 67 & 4.2 & 2 & -- & -- \\
\hline & & & & 5 & 364 & 367 & $\mathrm{U}$ & 44 & 2.7 & 2 & -- & -- \\
\hline & & & & 6 & 407 & 466 & $\mathrm{U}$ & 87 & 5.7 & 4 & -- & -- \\
\hline & & & & 7 & 343 & 258 & $\mathbf{M}$ & 34 & 1.6 & 2 & -- & - \\
\hline & & & & 8 & 344 & 279 & $\mathrm{U}$ & 52 & 2.6 & 2 & -- & -- \\
\hline Sample $n$ & & & & & $\overline{358}$ & $\overline{335}$ & & 56 & 3.3 & 2.3 & & \\
\hline
\end{tabular}


Appendix A.--Summary of parameters on individual fish collected during the Lake Roosevelt study--Continued

\begin{tabular}{|c|c|c|c|c|c|c|c|c|c|c|c|c|}
\hline Species & Site & $\begin{array}{l}\text { USGS } \\
\text { sample } \\
\text { code }\end{array}$ & $\begin{array}{l}\text { Size } \\
\text { class }\end{array}$ & $\begin{array}{l}\text { Repli- } \\
\text { cate }\end{array}$ & $\begin{array}{l}\text { Total } \\
\text { length } \\
(\mathrm{mm})\end{array}$ & $\begin{array}{l}\text { Total } \\
\text { weight } \\
\text { (grams) }\end{array}$ & $\begin{array}{l}\text { Gender } \\
\text { M-F-U }\end{array}$ & $\begin{array}{l}\text { Fillet } \\
\text { weight } \\
\text { (grams) }\end{array}$ & $\begin{array}{l}\text { Liver } \\
\text { weight } \\
\text { (grams) }\end{array}$ & $\begin{array}{l}\text { Age } \\
\text { (yrs) }\end{array}$ & $\begin{array}{l}\text { USGS } \\
\text { sample } \\
\text { code }\end{array}$ & $\begin{array}{l}\text { Fillet } \\
\text { weight } \\
\text { (grams) }\end{array}$ \\
\hline \multirow[t]{8}{*}{ Walleye } & \multirow[t]{8}{*}{ Spokane } & FDRSP1706- & \multirow[t]{8}{*}{2} & 1 & 345 & 351 & $\mathbf{M}$ & 53 & 1.5 & 2 & -- & -- \\
\hline & & \multirow[t]{7}{*}{ WAF8050 } & & 2 & 342 & 340 & $\mathrm{U}$ & 35 & 4.3 & 2 & - & -- \\
\hline & & & & 3 & 352 & 315 & $\mathbf{M}$ & 44 & 2.8 & 2 & - & -- \\
\hline & & & & 4 & 355 & 378 & $\mathbf{M}$ & 49 & 4.1 & 2 & -- & -- \\
\hline & & & & 5 & 345 & 349 & $\mathrm{~F}$ & 56 & 1.7 & 2 & -- & -- \\
\hline & & & & 6 & 345 & 290 & $\mathbf{U}$ & 31 & 1.5 & 2 & -- & -- \\
\hline & & & & 7 & 344 & 337 & $\mathrm{U}$ & 43 & 1.7 & 2 & -- & -- \\
\hline & & & & 8 & 342 & 321 & $\mathbf{M}$ & 43 & 1.2 & 2 & -- & $\cdots$ \\
\hline \multicolumn{2}{|c|}{ Sample mean } & & & & 346 & 335 & & 43 & 2.5 & 2.0 & & \\
\hline \multirow[t]{8}{*}{ Walleye } & \multirow[t]{8}{*}{ Spokane } & \multirow{8}{*}{$\begin{array}{l}\text { FDRSP1706- } \\
\text { WAF8061 }\end{array}$} & \multirow[t]{8}{*}{2} & 1 & 340 & 289 & $\mathbf{M}$ & 45 & 1.9 & 2 & -- & -- \\
\hline & & & & 2 & 375 & 434 & $\mathrm{U}$ & 46 & 5.5 & 4 & -- & -- \\
\hline & & & & 3 & 335 & 289 & $\mathrm{U}$ & 41 & 3.3 & 2 & -- & - \\
\hline & & & & 4 & 381 & 498 & $\mathbf{M}$ & 57 & 1.5 & 3 & - & $\cdots$ \\
\hline & & & & 5 & 355 & 340 & $\mathbf{M}$ & 39 & 0.6 & 2 & - & -- \\
\hline & & & & 6 & 340 & 262 & $\mathrm{~F}$ & 29 & 2.3 & 2 & - & - \\
\hline & & & & 7 & 340 & 322 & $\mathrm{U}$ & 44 & 1.7 & 2 & -- & -- \\
\hline & & & & 8 & 342 & 311 & $\mathrm{U}$ & 37 & 2.8 & 2 & -- & -- \\
\hline \multicolumn{2}{|c|}{ Sample mean } & & & & 351 & 343 & & 42 & 2.5 & 2.4 & & \\
\hline \multirow[t]{8}{*}{ Walleye } & \multirow[t]{8}{*}{ Spokane } & FDRSP1906- & \multirow[t]{8}{*}{2} & 1 & 365 & 372 & $\mathrm{U}$ & 57 & 0.1 & 2 & -- & -- \\
\hline & & \multirow[t]{7}{*}{ WAF8053 } & & 2 & 375 & 400 & $\mathrm{U}$ & 80 & 2.8 & 2 & -- & - \\
\hline & & & & 3 & 341 & 305 & $\mathbf{M}$ & 42 & 2.4 & 2 & - & - \\
\hline & & & & 4 & 355 & 304 & $\mathrm{U}$ & 56 & 3 & 2 & - & -- \\
\hline & & & & 5 & 390 & 460 & M & 48 & 4.2 & 2 & - & -- \\
\hline & & & & 6 & 360 & 329 & $\mathrm{U}$ & 64 & 3.4 & 2 & -- & - \\
\hline & & & & 7 & 345 & 312 & $\mathbf{M}$ & 42 & 2.4 & 2 & - & -- \\
\hline & & & & 8 & 340 & 294 & $\mathrm{U}$ & 63 & 2.7 & 2 & - & -- \\
\hline \multicolumn{2}{|c|}{ Sample mean } & & & & 359 & 347 & & 56 & 3.0 & 2.0 & & \\
\hline \multirow[t]{8}{*}{ Walleye } & \multirow[t]{8}{*}{ Spokane } & FDRSP1906- & \multirow[t]{8}{*}{2} & 1 & 350 & 309 & $\mathrm{U}$ & 40 & 3 & 2 & -- & -- \\
\hline & & WAF8054 & & 2 & 340 & 300 & $\mathrm{U}$ & 60 & 3.8 & 2 & -- & -- \\
\hline & & & & 3 & 375 & 416 & $\mathbf{U}$ & 64 & 2.9 & 2 & -- & -- \\
\hline & & & & 4 & 360 & 362 & $\mathrm{U}$ & 68 & 4.1 & 2 & -- & - \\
\hline & & & & 5 & 351 & 343 & $\mathrm{U}$ & 50 & 2.8 & 2 & -- & -- \\
\hline & & & & 6 & 364 & 382 & $\mathbf{M}$ & 78 & 4.5 & 2 & - & -- \\
\hline & & & & 7 & 360 & 318 & $\mathrm{U}$ & 43 & 3.8 & 2 & - & -- \\
\hline & & & & 8 & 357 & 399 & $\mathbf{M}$ & 71 & 3.4 & 2 & - & -- \\
\hline Sample $\mathrm{m}$ & & & & & 357 & 354 & & 62 & 3.6 & 2.0 & & \\
\hline
\end{tabular}


Appendix A.--Summary of parameters on individual fish collected during the Lake Roosevelt study--Continued

\begin{tabular}{|c|c|c|c|c|c|c|c|c|c|c|c|c|}
\hline Species & Site & $\begin{array}{l}\text { USGS } \\
\text { sample } \\
\text { code }\end{array}$ & $\begin{array}{l}\text { Size } \\
\text { class }\end{array}$ & $\begin{array}{l}\text { Repli- } \\
\text { cate }\end{array}$ & $\begin{array}{l}\text { Total } \\
\text { length } \\
(\mathrm{mm})\end{array}$ & $\begin{array}{l}\text { Total } \\
\text { weight } \\
\text { (grams) }\end{array}$ & $\begin{array}{l}\text { Gender } \\
\text { M-F-U }\end{array}$ & $\begin{array}{l}\text { Fillet } \\
\text { weight } \\
\text { (grams) }\end{array}$ & $\begin{array}{l}\text { Liver } \\
\text { weight } \\
\text { (grams) }\end{array}$ & $\begin{array}{l}\text { Age } \\
\text { (yrs) }\end{array}$ & $\begin{array}{l}\text { USGS } \\
\text { sample } \\
\text { code }\end{array}$ & $\begin{array}{l}\text { Fillet } \\
\text { weight } \\
\text { (grams) }\end{array}$ \\
\hline \multirow[t]{8}{*}{ Walleye } & \multirow[t]{8}{*}{ Spokane } & FDRSP1505- & \multirow[t]{8}{*}{3} & 1 & 451 & 777 & $\mathrm{~F}$ & 67 & 3.6 & 5 & -- & -- \\
\hline & & \multirow[t]{7}{*}{ WAF8009 } & & 2 & 430 & 533 & $\mathbf{M}$ & 94 & 6 & 3 & - & -- \\
\hline & & & & 3 & 411 & 565 & $\mathbf{M}$ & 81 & 2.3 & 2 & -- & -- \\
\hline & & & & 4 & 428 & 550 & $\mathbf{M}$ & 87 & 2.4 & 6 & -- & -- \\
\hline & & & & 5 & 440 & 636 & $\mathrm{~F}$ & 97 & 5.1 & 6 & -- & - \\
\hline & & & & 6 & 452 & 793 & $F$ & 139 & 5.3 & 6 & -- & -- \\
\hline & & & & 7 & 442 & 705 & $\mathbf{M}$ & 127 & 7.6 & 4 & -- & - \\
\hline & & & & 8 & 421 & 589 & M & 117 & 7 & 2 & -- & -- \\
\hline \multicolumn{2}{|c|}{ Sample mean } & & & & 434 & 644 & & 106 & 5.1 & 4.3 & & \\
\hline \multirow[t]{8}{*}{ Walleye } & \multirow[t]{8}{*}{ Spokane } & \multirow{8}{*}{$\begin{array}{l}\text { FDRSP1505- } \\
\text { WAF8010 }\end{array}$} & \multirow[t]{8}{*}{3} & 1 & 450 & 759 & $\mathrm{~F}$ & 71 & 2.7 & 6 & -- & -- \\
\hline & & & & 2 & 425 & 542 & $\mathbf{M}$ & 84 & 5.2 & 4 & -- & -- \\
\hline & & & & 3 & 423 & 632 & M & 117 & 6.6 & 4 & -- & -- \\
\hline & & & & 4 & 465 & 748 & $F$ & 77 & 6.1 & -- & -- & -- \\
\hline & & & & 5 & 433 & 597 & M & 90 & 7.1 & 4 & -- & -- \\
\hline & & & & 6 & 440 & 695 & M & 88 & 6.2 & 6 & -- & -- \\
\hline & & & & 7 & 419 & 591 & $\mathbf{M}$ & 112 & 4.7 & 4 & -- & -- \\
\hline & & & & 8 & 475 & 765 & $\mathbf{M}$ & 96 & 6.7 & 5 & -- & - \\
\hline \multicolumn{2}{|c|}{ Sample mean } & & & & 441 & 666 & & 95 & 6.1 & 4.7 & & \\
\hline \multirow[t]{8}{*}{ Walleye } & \multirow[t]{8}{*}{ Spokane } & \multirow{8}{*}{$\begin{array}{l}\text { FDRSP1906- } \\
\text { WAF8059 }\end{array}$} & \multirow[t]{8}{*}{3} & 1 & 443 & 706 & $\mathbf{M}$ & 135 & 4.2 & 4 & - & - \\
\hline & & & & 2 & 454 & 646 & $\mathbf{M}$ & 102 & 4 & 6 & -- & -- \\
\hline & & & & 3 & 430 & 625 & $\mathrm{~F}$ & 123 & 4.6 & 4 & -- & -- \\
\hline & & & & 4 & 413 & 527 & $\mathrm{~F}$ & 99 & 5.8 & 4 & -- & -- \\
\hline & & & & 5 & 437 & 557 & $\mathrm{M}$ & 57 & 6.4 & 4 & -- & -- \\
\hline & & & & 6 & 422 & 582 & $\mathbf{M}$ & 115 & 3.7 & 4 & -- & -- \\
\hline & & & & 7 & 435 & 648 & $\mathrm{~F}$ & 80 & 4.8 & 4 & -- & -- \\
\hline & & & & 8 & 460 & 766 & $\mathrm{~F}$ & 75 & 4.3 & 8 & -- & -- \\
\hline \multicolumn{2}{|c|}{ Sample mean } & & & & 437 & 632 & & 93 & 4.8 & 4.8 & & \\
\hline \multirow[t]{8}{*}{ Walleye } & \multirow[t]{8}{*}{ Spokane } & \multirow{8}{*}{$\begin{array}{l}\text { FDRSP1405- } \\
\text { WAF8001 }\end{array}$} & \multirow[t]{8}{*}{4} & 1 & 520 & 1000 & $\mathrm{M}$ & 67 & 8.8 & 5 & -- & $\ldots$ \\
\hline & & & & 2 & 510 & 1006 & $\mathrm{~F}$ & 63 & 7.2 & 5 & -- & $\ldots$ \\
\hline & & & & 3 & 495 & 1222 & $\mathrm{M}$ & 73 & 12.8 & 3 & -- & -- \\
\hline & & & & 4 & 510 & 994 & $\mathrm{M}$ & 64 & 11.4 & 8 & -- & -- \\
\hline & & & & 5 & 507 & 987 & $\mathbf{M}$ & 90 & 7.7 & 5 & -- & -- \\
\hline & & & & 6 & 500 & 959 & $\mathrm{~F}$ & 62 & 7.2 & 5 & -- & .. \\
\hline & & & & 7 & 508 & 1155 & $\mathrm{M}$ & 82 & 14.2 & 4 & -- & -. \\
\hline & & & & 8 & 490 & 948 & $\mathrm{M}$ & 86 & 10.4 & 5 & -- & -- \\
\hline \multicolumn{3}{|c|}{ Sample mean } & & & 505 & 1,034 & & 74 & 10.1 & 5.0 & & \\
\hline
\end{tabular}


Appendix A.--Summary of parameters on individual fish collected during the Lake Roosevelt study--Continued

\begin{tabular}{|c|c|c|c|c|c|c|c|c|c|c|c|c|}
\hline Species & Site & $\begin{array}{l}\text { USGS } \\
\text { sample } \\
\text { code }\end{array}$ & $\begin{array}{l}\text { Size } \\
\text { class }\end{array}$ & $\begin{array}{l}\text { Repli- } \\
\text { cate }\end{array}$ & $\begin{array}{l}\text { Total } \\
\text { length } \\
(\mathrm{mm})\end{array}$ & $\begin{array}{l}\text { Total } \\
\text { weight } \\
\text { (grams) }\end{array}$ & $\begin{array}{l}\text { Gender } \\
\text { M-F-U }\end{array}$ & $\begin{array}{l}\text { Fillet } \\
\text { weight } \\
\text { (grams) }\end{array}$ & $\begin{array}{l}\text { Liver } \\
\text { weight } \\
\text { (grams) }\end{array}$ & $\begin{array}{l}\text { Age } \\
\text { (yrs) }\end{array}$ & $\begin{array}{l}\text { USGS } \\
\text { sample } \\
\text { code }\end{array}$ & $\begin{array}{l}\text { Fillet } \\
\text { weight } \\
\text { (grams) }\end{array}$ \\
\hline \multirow[t]{8}{*}{ Walleye } & \multirow[t]{8}{*}{ Spokane } & FDRSP1405- & \multirow[t]{8}{*}{4} & 1 & 495 & 911 & $\mathrm{~F}$ & 62 & 7 & 4 & -- & -- \\
\hline & & \multirow{7}{*}{ WAF8002 } & & 2 & 500 & 939 & $\mathbf{M}$ & 91 & 9.7 & 4 & -- & - \\
\hline & & & & 3 & 483 & 747 & $\mathrm{~F}$ & 68 & 6.7 & 4 & -- & -- \\
\hline & & & & 4 & 535 & 1,242 & $\mathrm{~F}$ & 103 & 11.2 & 4 & -- & - \\
\hline & & & & 5 & 540 & 1,161 & $\mathbf{F}$ & 85 & 8.4 & 6 & -- & -- \\
\hline & & & & 6 & 500 & 1,019 & F & 71 & 11.2 & 4 & -- & -- \\
\hline & & & & 7 & 522 & 987 & $\mathbf{M}$ & 67 & 11.4 & 4 & -- & -- \\
\hline & & & & 8 & 524 & 1,165 & $\mathbf{M}$ & 108 & 10.3 & 4 & -- & -- \\
\hline \multicolumn{2}{|c|}{ Sample mean } & & & & 512 & 1,021 & & 85 & 9.8 & 4.3 & & \\
\hline \multirow[t]{8}{*}{ Walleye } & \multirow[t]{8}{*}{ Sanpoil } & \multirow{8}{*}{$\begin{array}{l}\text { FDRSA1605- } \\
\text { WAF8012 }\end{array}$} & \multirow[t]{8}{*}{1} & 1 & 305 & 209 & $\mathrm{U}$ & 21 & 2.1 & 1 & -- & -- \\
\hline & & & & 2 & 315 & 219 & $\mathrm{U}$ & 30 & 3.3 & 2 & -- & -- \\
\hline & & & & 3 & 311 & 215 & $\mathrm{U}$ & 28 & 1.5 & 1 & -- & -- \\
\hline & & & & 4 & 315 & 218 & $\mathrm{U}$ & 29 & 2.6 & 2 & -- & -- \\
\hline & & & & 5 & 290 & 171 & $\mathrm{U}$ & 22 & 1.6 & 1 & -- & -- \\
\hline & & & & 6 & 310 & 216 & $\mathrm{U}$ & 32 & 2 & 2 & -- & -- \\
\hline & & & & 7 & 303 & 214 & $\mathrm{U}$ & 34 & 2 & 1 & -- & -- \\
\hline & & & & 8 & 285 & 176 & $\mathrm{U}$ & 25 & 0.7 & 1 & -- & -- \\
\hline \multicolumn{2}{|c|}{ Sample mean } & & & & 304 & 205 & & 29 & 2.0 & 1.4 & & \\
\hline \multirow[t]{8}{*}{ Walleye } & \multirow[t]{8}{*}{ Sanpoil } & \multirow{8}{*}{$\begin{array}{l}\text { FDRSA1605- } \\
\text { WAF8011 }\end{array}$} & \multirow[t]{8}{*}{2} & 1 & 355 & 370 & $\mathrm{U}$ & 50 & 3.9 & 2 & -- & -- \\
\hline & & & & 2 & 360 & 379 & $\mathrm{U}$ & 24 & 2.1 & 3 & -- & -- \\
\hline & & & & 3 & 345 & 293 & $\mathbf{M}$ & 39 & 3.4 & 2 & -- & -- \\
\hline & & & & 4 & 342 & 304 & M & 30 & 2.4 & 2 & -- & -- \\
\hline & & & & 5 & 365 & 369 & $\mathrm{U}$ & 36 & 4 & 2 & -- & -- \\
\hline & & & & 6 & 353 & 363 & $\mathrm{U}$ & 51 & 3.2 & 2 & -- & -- \\
\hline & & & & 7 & 361 & 373 & $\mathrm{M}$ & 32 & 4.4 & 2 & -- & -- \\
\hline & & & & 8 & 341 & 300 & $\mathrm{U}$ & 41 & 3.4 & 2 & - & -- \\
\hline \multicolumn{2}{|c|}{ Sample mean } & & & & 353 & 344 & & 36 & 3.3 & 2.1 & & \\
\hline \multirow[t]{8}{*}{ Walleye } & \multirow[t]{8}{*}{ Sanpoil } & \multirow{8}{*}{$\begin{array}{l}\text { FDRSA1805- } \\
\text { WAF } 8027\end{array}$} & \multirow[t]{8}{*}{2} & 1 & 380 & 439 & $\mathrm{M}$ & 52 & 5.8 & 2 & F1027.1 & 141 \\
\hline & & & & 2 & 373 & 406 & $\mathrm{U}$ & 61 & 2.9 & 1 & F1027.2 & 257 \\
\hline & & & & 3 & 400 & 466 & $\mathrm{M}$ & 53 & 4.1 & 3 & F1027.3 & 341 \\
\hline & & & & 4 & 403 & 484 & $\mathrm{M}$ & 71 & 4.3 & 3 & F1027.4 & 460 \\
\hline & & & & 5 & 395 & 494 & $\mathrm{M}$ & 50 & 3.1 & 4 & F1027.5 & .536 \\
\hline & & & & 6 & 388 & 401 & $\mathbf{M}$ & 56 & 4.6 & 4 & F1027.6 & 649 \\
\hline & & & & 7 & 340 & 248 & $\mathrm{~F}$ & 34 & 2.9 & 3 & F1027.7 & .727 \\
\hline & & & & 8 & 359 & 337 & $\mathrm{~F}$ & 54 & 2.5 & 2 & F1027.8 & 845 \\
\hline \multicolumn{2}{|c|}{ Sample mean } & & & & 380 & 409 & & 54 & 3.5 & 2.8 & & \\
\hline
\end{tabular}


Appendix A.--Summary of parameters on individual fish collected during the Lake Roosevelt study--Continued

\begin{tabular}{|c|c|c|c|c|c|c|c|c|c|c|c|c|}
\hline Species & Site & $\begin{array}{l}\text { USGS } \\
\text { sample } \\
\text { code }\end{array}$ & $\begin{array}{l}\text { Size } \\
\text { class }\end{array}$ & $\begin{array}{l}\text { Repli- } \\
\text { cate }\end{array}$ & $\begin{array}{l}\text { Total } \\
\text { length } \\
(\mathrm{mm})\end{array}$ & $\begin{array}{l}\text { Total } \\
\text { weight } \\
\text { (grams) }\end{array}$ & $\begin{array}{l}\text { Gender } \\
\text { M-F-U }\end{array}$ & $\begin{array}{l}\text { Fillet } \\
\text { weight } \\
\text { (grams) }\end{array}$ & $\begin{array}{l}\text { Liver } \\
\text { weight } \\
\text { (grams) }\end{array}$ & $\begin{array}{l}\text { Age } \\
\text { (yrs) }\end{array}$ & $\begin{array}{l}\text { USGS } \\
\text { sample } \\
\text { code }\end{array}$ & $\begin{array}{l}\text { Fillet } \\
\text { weight } \\
\text { (grams) }\end{array}$ \\
\hline \multirow[t]{8}{*}{ Walleye } & \multirow[t]{8}{*}{ Sanpoil } & FDRSA1605- & \multirow[t]{8}{*}{3} & 1 & 445 & 658 & $\mathrm{~F}$ & 42 & 4.9 & 5 & -- & -- \\
\hline & & \multirow[t]{7}{*}{ WAF8013 } & & 2 & 415 & 481 & M & 54 & 3.2 & 4 & -- & -- \\
\hline & & & & 3 & 413 & 594 & M & 63 & 3.7 & 5 & -- & -- \\
\hline & & & & 4 & 418 & 568 & M & 62 & 5.3 & 3 & -- & -- \\
\hline & & & & 5 & 410 & 570 & M & 79 & 5.9 & 3 & -- & -- \\
\hline & & & & 6 & 445 & 795 & $\mathrm{~F}$ & 109 & 8.6 & 2 & $\cdots$ & -. \\
\hline & & & & 7 & 425 & 621 & $\mathrm{~F}$ & 65 & 5.7 & 2 & - & -- \\
\hline & & & & 8 & 446 & 649 & M & 88 & 8.6 & 3 & -- & -- \\
\hline \multicolumn{2}{|c|}{ Sample mean } & & & & 427 & 617 & & 74 & 5.9 & 3.4 & & \\
\hline \multirow[t]{8}{*}{ Walleye } & \multirow[t]{8}{*}{ Sanpoil } & FDRSA1705- & \multirow[t]{8}{*}{3} & 1 & 412 & 638 & $\mathrm{~F}$ & 79 & 5.7 & 3 & -- & -- \\
\hline & & \multirow[t]{7}{*}{ WAF8023 } & & 2 & 464 & 922 & $\mathrm{~F}$ & 128 & 11 & 3 & -- & -- \\
\hline & & & & 3 & 444 & 757 & $\mathrm{~F}$ & 105 & 9.1 & 3 & $\ldots$ & -- \\
\hline & & & & 4 & 423 & 674 & $\mathrm{~F}$ & 107 & 12.3 & 3 & - & -- \\
\hline & & & & 5 & 425 & 688 & $\mathrm{U}$ & 94 & 4.9 & 2 & -- & -- \\
\hline & & & & 6 & 448 & 781 & $\mathbf{M}$ & 102 & 11.4 & 2 & -- & -- \\
\hline & & & & 7 & 425 & 691 & $\mathrm{U}$ & 78 & 5.6 & 2 & -- & -- \\
\hline & & & & 8 & 432 & 659 & M & 75 & 4.3 & 4 & - & -- \\
\hline \multicolumn{2}{|c|}{ Sample mean } & & & & 434 & 726 & & 98 & 8.4 & 2.8 & & \\
\hline \multirow{5}{*}{$\begin{array}{l}\text { Small- } \\
\text { mouth } \\
\text { bass }\end{array}$} & \multirow[t]{5}{*}{ Spokane } & FDRSP1705- & \multirow[t]{5}{*}{--} & 1 & 210 & 136 & M & 13 & 1.6 & 1 & -- & -- \\
\hline & & \multirow[t]{4}{*}{ SMF5028 } & & 2 & 241 & 201 & M & 25 & 2 & 2 & -- & -- \\
\hline & & & & 3 & 275 & 323 & $\mathrm{~F}$ & 32 & 3.9 & 2 & -- & -- \\
\hline & & & & 4 & 280 & 349 & $\mathrm{~F}$ & 36 & 4.7 & 2 & $\ldots$ & -- \\
\hline & & & & 5 & 235 & 173 & M & 17 & 1.3 & 2 & - & -- \\
\hline \multicolumn{2}{|c|}{ Sample mean } & & & & 248 & 236 & & 25 & 2.7 & 1.8 & & \\
\hline \multirow{5}{*}{$\begin{array}{l}\text { Small- } \\
\text { mouth } \\
\text { bass }\end{array}$} & \multirow[t]{5}{*}{ Spokane } & \multirow{5}{*}{$\begin{array}{l}\text { FDRSP1705- } \\
\text { SMF5029 }\end{array}$} & \multirow[t]{5}{*}{--} & 1 & 265 & 246 & $\mathrm{~F}$ & 17 & 2.7 & 2 & -- & -- \\
\hline & & & & 2 & 287 & 286 & $\mathrm{~F}$ & 37 & 3.3 & 2 & - & -- \\
\hline & & & & 3 & 270 & 300 & $\mathrm{M}$ & 32 & 4.1 & 2 & -- & -- \\
\hline & & & & 4 & 279 & 278 & $\mathrm{~F}$ & 29 & 3.7 & 2 & -- & -- \\
\hline & & & & 5 & 231 & 157 & $\mathrm{~F}$ & 20 & 1.5 & 2 & - & -- \\
\hline \multicolumn{2}{|c|}{ Sample mean } & & & & 266 & 253 & & 27 & 3.1 & 2.0 & & \\
\hline \multirow{5}{*}{$\begin{array}{l}\text { Small- } \\
\text { mouth } \\
\text { bass }\end{array}$} & \multirow[t]{5}{*}{ Sanpoil } & \multirow{5}{*}{$\begin{array}{l}\text { FDRSA1805- } \\
\text { SMF5024 }\end{array}$} & \multirow[t]{5}{*}{--} & 1 & 260 & 207 & $\mathrm{~F}$ & 18 & 2.1 & 2 & - & -- \\
\hline & & & & 2 & 258 & 218 & $\mathbf{M}$ & 16 & 2.9 & 2 & -- & -- \\
\hline & & & & 3 & 250 & 232 & $\mathrm{~F}$ & 24 & 2.5 & 2 & -- & -- \\
\hline & & & & 4 & 257 & 246 & $\mathbf{M}$ & 16 & 4.1 & 2 & -- & -- \\
\hline & & & & 5 & 290 & 318 & $\mathbf{M}$ & 30 & 3.9 & 2 & -- & -- \\
\hline Sample & & & & & 263 & 244 & & 21 & 3.1 & 2.0 & & \\
\hline
\end{tabular}


Appendix A.--Summary of parameters on individual fish collected during the Lake Roosevelt study--Continued

\begin{tabular}{|c|c|c|c|c|c|c|c|c|c|c|c|c|}
\hline Species & Site & $\begin{array}{l}\text { USGS } \\
\text { sample } \\
\text { code }\end{array}$ & $\begin{array}{l}\text { Size } \\
\text { class }\end{array}$ & $\begin{array}{l}\text { Repli- } \\
\text { cate }\end{array}$ & $\begin{array}{l}\text { Total } \\
\text { length } \\
(\mathrm{mm})\end{array}$ & $\begin{array}{l}\text { Total } \\
\text { weight } \\
\text { (grams) }\end{array}$ & $\begin{array}{l}\text { Gender } \\
\mathrm{M}-\mathrm{F}-\mathrm{U}\end{array}$ & $\begin{array}{l}\text { Fillet } \\
\text { weight } \\
\text { (grams) }\end{array}$ & $\begin{array}{l}\text { Liver } \\
\text { weight } \\
\text { (grams) }\end{array}$ & $\begin{array}{l}\text { Age } \\
\text { (yrs) }\end{array}$ & $\begin{array}{l}\text { USGS } \\
\text { sample } \\
\text { code }\end{array}$ & $\begin{array}{l}\text { Fillet } \\
\text { weight } \\
\text { (grams) }\end{array}$ \\
\hline \multirow{5}{*}{$\begin{array}{l}\text { Small- } \\
\text { mouth } \\
\text { bass }\end{array}$} & \multirow[t]{5}{*}{ Sanpoil } & FDRSA1805- & \multirow[t]{5}{*}{-- } & 1 & 250 & 214 & $\mathbf{M}$ & 13 & 2.6 & 2 & -- & -- \\
\hline & & \multirow[t]{4}{*}{ SMF5025 } & & 2 & 281 & 348 & $\mathbf{M}$ & 31 & 4.6 & 2 & -- & -- \\
\hline & & & & 3 & 252 & 205 & $F$ & 22 & 1.9 & 2 & -- & -- \\
\hline & & & & 4 & 258 & 268 & M & 17 & 4 & 2 & -- & -- \\
\hline & & & & 5 & 267 & 278 & M & 19 & 4.6 & 3 & -- & -- \\
\hline \multicolumn{2}{|c|}{ Sample mean } & & & & 262 & 263 & & 20 & 3.5 & 2.2 & & \\
\hline \multirow{5}{*}{$\begin{array}{l}\text { Small- } \\
\text { mouth } \\
\text { bass }\end{array}$} & \multirow[t]{5}{*}{ Sanpoil } & FDRSA $1805-$ & \multirow[t]{5}{*}{--} & 1 & 250 & 233 & $\mathrm{~F}$ & 26 & 4.7 & 2 & - & -- \\
\hline & & \multirow[t]{4}{*}{ SMF5026 } & & 2 & 282 & 299 & $\mathbf{F}$ & 24 & 5.2 & 3 & -- & -- \\
\hline & & & & 3 & 251 & 214 & $\mathbf{M}$ & 23 & 3.9 & 2 & -- & -- \\
\hline & & & & 4 & 252 & 228 & $\mathrm{~F}$ & 14 & 2.7 & 2 & -- & -- \\
\hline & & & & 5 & 256 & 223 & M & 24 & 3.4 & 2 & -- & -- \\
\hline \multicolumn{2}{|c|}{ Sample mean } & & & & 258 & 239 & & 22 & 4.0 & 2.2 & & \\
\hline \multicolumn{2}{|l|}{$\begin{array}{l}\text { Native } \\
\text { rainbow }\end{array}$} & FDRKF1905- & & & & & & & & & & \\
\hline trout & Kettle & RTF1031 & -- & 1 & 520 & 1,245 & $\mathrm{~F}$ & 142 & 12.3 & 5 & -- & -- \\
\hline \multicolumn{2}{|l|}{$\begin{array}{l}\text { Native } \\
\text { rainbow }\end{array}$} & FDRKF1905- & & & & & & & & & & \\
\hline trout & Kettle & RTF1032 & -- & 1 & 510 & 996 & $\mathrm{~F}$ & 128 & 6.6 & 4 & -- & -- \\
\hline \multicolumn{2}{|l|}{$\begin{array}{l}\text { Native } \\
\text { rainhow }\end{array}$} & FDRSA 1905- & & & & & & & & & & \\
\hline trout & Sanpoil & RTF1033 & -- & 1 & 510 & 1,216 & $\mathbf{F}$ & 138 & 15.7 & 5 & -- & -- \\
\hline \multicolumn{2}{|l|}{ Native } & FDRSA 1905- & & & & & & & & & & \\
\hline trout & Sanpoil & RTF1034 & -- & 1 & 505 & 1,086 & M & 211 & 17 & 5 & -- & -. \\
\hline \multicolumn{2}{|l|}{$\begin{array}{l}\text { Native } \\
\text { rainbow }\end{array}$} & FDRSA1905- & & & & & & & & & & \\
\hline trout & Sanpoil & RTF1035 & -- & 1 & 540 & 1,188 & $\mathrm{~F}$ & 121 & 22.1 & 4 & -- & -- \\
\hline \\
\hline trout & Sanpoil & RTF1036 & -- & 1 & 490 & 1,055 & M & 200 & 12.2 & 4 & -- & -- \\
\hline \multicolumn{2}{|l|}{$\begin{array}{l}\text { Net-pen } \\
\text { rainbow }\end{array}$} & FDRSA1905- & & & & & & & & & & \\
\hline trout & Sanpoil & RTF1037 & -- & 1 & 455 & 1,219 & F & 91 & 7 & 3 & -- & -- \\
\hline \multicolumn{13}{|l|}{ Net-pen } \\
\hline trout & Sanpoil & RTF1038 & -. & 1 & 510 & 1,563 & $\mathbf{M}$ & 187 & 20.8 & 3 & -- & -- \\
\hline
\end{tabular}

